\title{
26. LATE PLIOCENE-QUATERNARY BIOSILICEOUS SEDIMENTATION AT SITE 798, JAPAN SEA ${ }^{1}$
}

\author{
Robert B. Dunbar, ${ }^{2}$ Peter B. deMenocal, ${ }^{3}$ and Lloyd Burckle ${ }^{3}$
}

\begin{abstract}
Upper Pliocene through Holocene sediments recovered at Site 798 in the Japan Sea (Oki Ridge) exhibit rhythmic variation in weight percent biogenic opal at intervals of $\sim 5 \mathrm{~m}$ and periods equivalent to the $41-\mathrm{k} . y$. obliquity cycle. Variance at 17 and 100 k.y. is observed prior to $1.3 \mathrm{Ma}$. These cycles are also clearly defined by log data and correspond to clusters of decimeter-scale dark-colored sediment units alternating with clusters of light-colored units. Opal content varies between $3 \%$ and $22 \%$ between 0 and $1.3 \mathrm{Ma}$ and from $3 \%$ to $43 \%$ between 1.3 and $2.6 \mathrm{Ma}$. Long-term opal accumulation rates average $1.8 \mathrm{~g} / \mathrm{cm}^{2} / \mathrm{k} . \mathrm{y}$. in the late Pliocene/early Pleistocene and decrease by about $60 \%$ at $\sim 1.3 \mathrm{Ma}$. Rough calculations suggest that opal accumulation rates increased and terrigenous flux decreased during the Holocene relative to the last glacial period. Our age control is not yet sufficient to allow a similar analysis of the 41-k.y. cyclicity in opal content throughout the Pleistocene.

Stable isotope results from planktonic foraminifers confirm previous suggestions of a strong surface-water freshening event during isotope stage 2; however, this episode appears to be unique during the Pleistocene. Benthic foraminifers are depleted in ${ }^{18} \mathrm{O}$ during parts of glacial stages 2 and 6 relative to adjacent interglacials, suggesting unusual warming and/or freshening of deep waters. Collectively, the stable isotope and \%opal data are consistent with continuing isolation of the Japan Sea during the Quaternary with important transitions occurring at $1.3,0.7$ to 1.0 , and 0.2 to $0.3 \mathrm{Ma}$.

Complex relationships among the stable isotope results, \%opal data, and sediment characteristics such as color and organic and inorganic carbon content preclude development of a simple model to explain cyclical sedimentation. Opal maxima occur within both light and dark intervals and the processes that control surface-water productivity are at times decoupled from the factors that regulate deep-water dysaerobia. We suggest that water column overturn is controlled largely by regional atmospheric circulation that must also have an as yet poorly understood effect on surface-water fertility.
\end{abstract}

\section{INTRODUCTION}

An intriguing feature of late Neogene deposition in the North Pacific is the sudden appearance of sediments enriched in biosiliceous debris at about 15-18 Ma (Ingle, 1981; Akiba, 1986; Barron and Baldauf, 1989). Similar enrichment is not observed in the North Atlantic or Indian oceans. Barron and Baldauf (1990) reviewed possible causes for this event in the North Pacific and noted that it precedes major cooling episodes in middle and high latitudes by 2 to 3 m.y. They suggested a link to the onset of North Atlantic Deep Water formation beginning about 17-18 Ma. In this scenario, the development of the modern deep-water circulation pattern led to the transfer of deep nutrient-rich waters from the Atlantic to the Pacific, thereby enhancing biosiliceous productivity and leading to the present basinbasin fractionation of siliceous and calcareous sediments. Subsequently, a series of cooling events beginning in the mid-Miocene influenced global and regional patterns of biosiliceous sedimentation. Coincident with decreased biosiliceous accumulation in the equatorial and northeastern Pacific in the early Pliocene (Leinen, 1979; Barron, 1981), the Southern Ocean emerged as an additional depocenter for biogenic opal as the Antarctic Circumpolar Current system strengthened (Brewster, 1980). Associated with continued cooling and development of the Northern Hemisphere ice sheets, biosiliceous deposition reappeared in limited areas of the North Atlantic during the late Pliocene (Baldauf, 1986).

Although they fit roughly into this generalized view of Neogene biosiliceous sedimentation, each marginal basin of the Pacific has its own unique history of biogenic sediment accumulation. The complex topography of these basins as well as the interplay of regional tectonic events with global climatic change produces considerable variability in the precise timing and location of biosiliceous sedimentation

${ }^{1}$ Pisciotto, K. A., Ingle, J. C., Jr., von Breymann, M. T., Barron, J., et al,, 1992. Proc. ODP, Sci. Results, 127/128, Pt. 1: College Station, TX (Ocean Drilling Program).

Department of Geology and Geophysics, Rice University, Houston, TX 77251, U.S.A.

${ }^{3}$ Lamont-Doherty Geological Observatory, Palisades, NY 10964, U.S.A. events. Regardless of where and when they occur, a feature common to biosiliceous sedimentation in most of these basins is a rhythmic meter- to decimeter-scale variation in biogenic silica content. In Miocene sediments of Japan and California, these bedding variations occur at periods of several thousand to tens of thousands of years (Tada, 1991; Pisciotto and Garrison, 1981) and may be orbitally forced. The extent to which these cycles reflect changes in productivity vs, terrigenous supply or possibly even diagenetic processes is not yet well understood.

Collectively, the marginal basins of the North Pacific are important for the global silica cycle because of their large area and high accumulation rates. When proper conditions prevail, opal deposition rates within specific basins may be 2 to 4 orders of magnitude higher than at the deep seafloor of the Pacific. For example, Tada (1991) reported opal fluxes to the middle Miocene Onnagawa Formation of northern Japan of 15 to $40 \mathrm{~g} / \mathrm{cm}^{2} / \mathrm{k}$.y., values similar to those reported for late Miocene/early Pliocene age sediments of the Santa Barbara Basin in California (Isaacs, 1985) and approximately 2 to 3 orders of magnitude greater than the global average rate of Si removal to marine sediments (calculated from DeMaster, 1981).

While a fairly comprehensive view of Neogene sedimentation in the equatorial and northeast Pacific is emerging (Ingle, 1973; Leinen, 1979; Barron, 1985, 1986; and many others), considerably less is known about the response of the marginal seas of the northwest Pacific to Miocene-Holocene tectonic events and climatic changes. Barron and Baldauf (1990) suggested that biosiliceous sedimentation in the Sea of Okhotsk and the Bering Sea increased significantly between 6.5 and $4.5 \mathrm{Ma}$. These marginal seas are presently the site of rapid accumulation of opal, accounting for the removal of about 0.42 $\times 10^{14} \mathrm{~g} \mathrm{SiO}_{2} / \mathrm{yr}$, or approximately $7 \%$ of the annual supply of silica from rivers and submarine hydrothermal sources (DeMaster, 1981). The extent to which the Japan Sea has acted as a late Neogene silica sink is not yet known. There is virtually no quantitative information available on Pliocene through Pleistocene biosiliceous sediment accumulation in the Japan Sea.

One goal of our Leg 128 research is to assess high-frequency as well as long-term variations in opal content and accumulation rate at 
two sites in the Japan Sea and to elucidate climatic and tectonic controls on biogenic sedimentation. Here, we present results from upper Pliocene through Holocene sediments cored at Ocean Drilling Program (ODP) Site 798. We sampled this sequence at time intervals ranging from 1000 to $4000 \mathrm{yr}$ and our results provide one of the highest resolution records of opal variation yet available for a North Pacific marginal basin. We also present preliminary results from oxygen isotope analyses of benthic and planktonic foraminifers retrieved from the latest Pleistocene age section at this site. Although we use the stable isotope data primarily for development of an age model, our results also help constrain models for environmental changes in the Japan Sea. A more thorough discussion of both carbon and oxygen isotopic results from several species of benthic foraminifers is being prepared as a separate submission.

\section{JAPAN SEA OCEANOGRAPHY AND SITE 798}

The Japan Sea consists of several deep basins ( $>3000 \mathrm{~m}$ water depth) separated by a series of banks and ridges underlain by continental crust (Tamaki, 1988). Water exchange between the Japan Sea and the adjacent Pacific Ocean and marginal seas occurs through four narrow and shallow sills, the Mamiya (12 m), Soya (55 m), Tsugaru $(130 \mathrm{~m})$, and Tsushima $(130 \mathrm{~m})$ straits (Fig. 1). Quaternary deformation within the eastern Japan Sea is significant and the configuration and depth of the sills has likely evolved in response to both tectonism and erosion/deposition events related to eustatic sea-level change. The sills undoubtedly exerted a strong influence on the oceanography of the Japan Sea during the most recent glacial event, when eustatic lowering of sea level resulted in emergence of the Mamiya and Soya straits and possibly the Tsugaru and Tsushima straits as well. The extent to which episodic isolation of the Japan Sea occurred throughout the Pleistocene is unclear; however, Matoba (1984) and Chinzei (1978) cited foraminiferal and molluscan evidence for substantial deep-water exchange with the Pacific at several times during the Miocene through early Pleistocene.

In the modern Japan Sea, warm saline surface water derived from the Kuroshio Current enters the sea from the south as the Tsushima Current. The Tsushima Current flows northward through the eastern Japan Sea and exits to the North Pacific mostly through the Tsugaru Strait. Surface-water exchange through the two northernmost straits is relatively minor because of their shallow sill depths. Cold, less saline surface waters flow south in the western Japan Sea as the locally derived Liman and North Korean currents.

Because water exchange with the Pacific is limited to the uppermost part of the water column, Japan Sea deep waters have their own unique hydrographic properties. Intense convective overturn, the result of extreme winter cooling and sea ice formation in the northern Japan Sea, has produced a modern deep-water column that is cold and isothermal $\left(0^{\circ}-1^{\circ} \mathrm{C}\right)$ below $350 \mathrm{~m}$ and well oxygenated $(5$ to $7 \mathrm{~mL} / \mathrm{L})$ (Hidaka, 1966; Yasui et al., 1967; Matoba, 1984). Ingle (in Ingle, Suyehiro, von Breymann, et al., 1990) suggested that deep-water formation via mixing and caballing of the Tsushima and Liman currents may also contribute to the rapid ventilation of the Japan Sea.

Cold oxic deep waters have greatly influenced modern sedimentation in the Japan Sea and are thought to be responsible for the occurrence of carbonate-poor "red clay" sediments depleted in organic matter (Niino et al., 1969; Ujiie and Ichikura, 1973). Ichikura and Ujiie (1976) have suggested a depth range of 1500 to $2100 \mathrm{~m}$ for the present-day carbonate compensation depth (CCD). It is unlikely that the CCD was significantly deeper during the late Neogene. The carbonate content of late Miocene through Quaternary age sediments in deep basins of the Japan Sea (ODP Sites 794-797 at water depths of 2570 to $3300 \mathrm{~m}$ ) is generally less than $1 \%$ and foraminiferal preservation is poor, consistent with deposition below the CCD (Tamaki, Pisciotto, Allan, et al., 1990).
A primary objective of scientific drilling in the Japan Sea during Leg 128 was recovery of a Miocene through Holocene paleoceanographic "reference" section for the Japan Sea. The target for this effort, Site 798, is located on the Oki Ridge in the southeastern Japan Sea at a depth of $911 \mathrm{~m}$ (Fig. 1). The Oki Ridge is separated from the Japanese island arc by the deep Oki Trough and thus receives little coarse terrigenous detritus. Carbonate preservation is enhanced compared with other sites drilled during Legs 127 and 128 because of its shallow depth. The sedimentary sequence recovered at Site 798 consists of $514 \mathrm{~m}$ of biosiliceous pelagic and hemipelagic sediments of early Pliocene through Holocene age. With an average (and relatively constant) sedimentation rate of $12 \mathrm{~cm} / \mathrm{k} . \mathrm{y}$. during the past 2.5 m.y., this site contains the most continuous and rapidly accumulated late Pliocene sequence recovered during Legs 127 and 128. In our study, we have focused on the biosiliceous component within the upper $320 \mathrm{~m}$, well above the level at which diagenetic dissolution of opal begins.

\section{METHODS}

Five- or 10-mL samples were collected aboard ship at intervals of approximately 15 to $20 \mathrm{~cm}$ throughout the upper $90 \mathrm{~m}$ of Hole $798 \mathrm{~A}$ and upper $20 \mathrm{~m}$ of Hole $798 \mathrm{C}$. Below $90 \mathrm{~m}$ below seafloor (mbsf), shipboard samples were collected at intervals of 0.5 to $1 \mathrm{~m}$ in Holes 798 A and 798B. In Cores 128-798B-13H through 128-798B-15H, continuous 30-cm-long "channel" samples were collected and homogenized for analysis. In Cores 128-798B-19X, 128-798B-20X, and $128-798 \mathrm{~B}-28 \mathrm{X}$ through $128-798 \mathrm{~B}-33 \mathrm{X}$, ODP curatorial restrictions did not permit continuous sampling. Instead, three 5-mL samples were collected every $10 \mathrm{~cm}$ and homogenized as one compound sample. The $30-\mathrm{cm}$ sampling strategy for these cores was employed to mimic the vertical aperture properties of the logging tools. deMenocal et al. (this volume) discussed the relation between sediment chemistry and downhole log data for Cores 128-798B-13H through $128-798 \mathrm{~B}-15 \mathrm{H}$ and their paleoclimatic significance.

A total of 913 samples was analyzed for weight percent biogenic silica (Appendix). Three-hundred thirty eight samples were analyzed at Rice University using the time-series dissolution technique of DeMaster (1981). By this method, opaline phases are dissolved in $0.1 \mathrm{~N} \mathrm{NaOH}$ at $85^{\circ} \mathrm{C}$ for $5 \mathrm{hr}$, with aliquots collected at hourly intervals for the measurement of dissolved silica. Biogenic opal dissolves more rapidly than other silica-bearing phases. By extrapolating the dissolved silica concentration back to time 0 (i.e., the start of the experiment), this technique corrects for silica dissolving from nonopaline phases. The remaining samples were analyzed at LamontDoherty Geological Observatory following the procedures outlined in Mortlock and Froelich (1989). This is a one-step dissolution method using a stronger base $\left(2 \mathrm{M} \mathrm{Na}_{2} \mathrm{CO}_{3}\right)$ following sample pretreatment with $\mathrm{H}_{2} \mathrm{O}_{2}$ and $\mathrm{HCl}$. Although this method does not compensate for silica dissolving from nonopaline phases, Mortlock and Froelich (1989) cited evidence that in most marine sediments, errors produced by leaching of silica from aluminosilicates is small compared with the range of opal contents. We note, however, that in sediments that contain quantities of very fine volcanic glass, the single-step dissolution method will likely yield high estimates of percent biogenic opal. In general, the results from both techniques at Site 798 compare favorably, although the one-step method yields opal contents that are consistently lower by $5 \%$ to $10 \%$ in most opal-enriched samples. The reason for this difference is not yet clear; one possibility is reduced $\mathrm{Si}$ activity due to polymerization in samples dissolved in the stronger base. For the purposes of this paper the difference between the two methods is small, and to merge the two data sets we have presented the Rice data as weight percent biogenic $\mathrm{SiO}_{2}$, whereas the L-DGO data have been corrected for an average water content of $10 \%$ and are thus weight percent biogenic opal. 


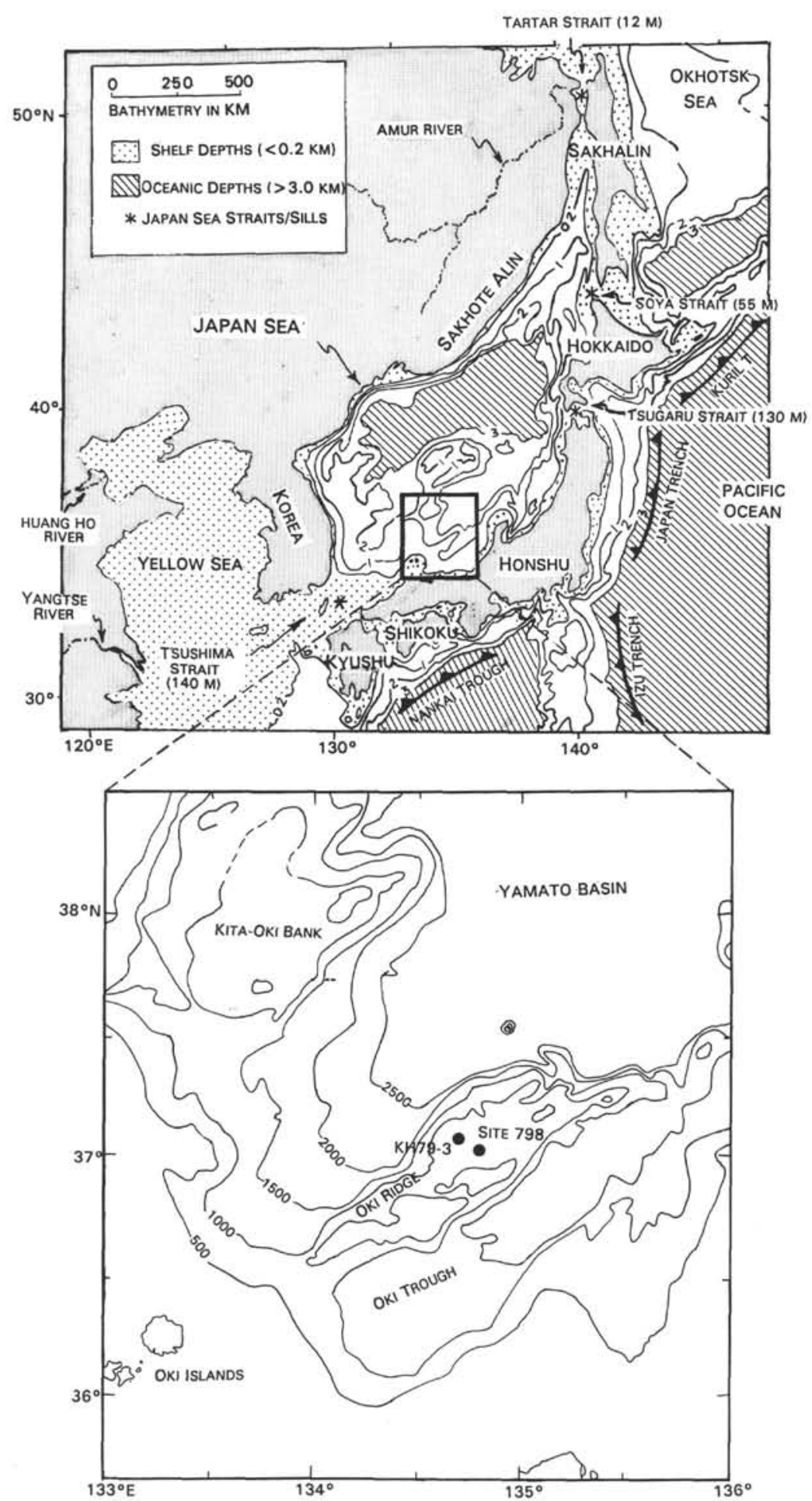

Figure 1. Map of the Japan Sea and Oki Ridge, showing the location of Site 798 and cores KH-79 L3 and C3 studied by Oba (1984). From Ingle, Suyehiro, von Breymann, et al. (1990). Water depths in kilometers in the upper diagram and in meters in the lower diagram.

Equivalent values are thus attained where we have overlapping samples. The precision for both techniques is similar: roughly $4 \%$ to $6 \%$ of the mean biogenic silica content.

Samples for oxygen isotope studies were wet sieved through a $62-\mu \mathrm{m}$ screen following disaggregation in a buffered Calgon solution. The planktonic foraminifer Globigerina bulloides and benthic fora- minifer Uvigerina akitaensis were picked from the $>250-\mu \mathrm{m}$ fraction. At least $25 \mathrm{G}$. bulloides and eight Uvigerina were analyzed at each depth. Replicates were run on about $15 \%$ of the samples, including the low- $\delta^{18} \mathrm{O} G$. bulloides sample at $3.02 \mathrm{mbsf}$. Samples were dissolved in $100 \%$ phosphoric acid at $50^{\circ} \mathrm{C}$; the resulting $\mathrm{CO}_{2}$ was analyzed with a V.G. Micromass isotope ratio mass spectrometer at 
Rice University. Analytical precision for $\delta^{18} \mathrm{O}$ is about $0.11 \%$ for replicates of foraminifers.

Sample depths used in this paper are composites based on several corrections. ODP depths are adjusted so that recovered core equals $100 \%$ of the cored interval for all cores with reported recoveries in excess of $100 \%$. We have also adjusted the depths for Holes 798A, $798 \mathrm{~B}$, and $798 \mathrm{C}$ based on offsets in paleomagnetic boundaries and our opal data where data sets from different cores overlap. We have added or subtracted the following amounts from the corrected ODP depths: $798 \mathrm{~A}=+3.2 \mathrm{~m}, 798 \mathrm{~B}=-0.8 \mathrm{~m}, 798 \mathrm{C}=0 \mathrm{~m}$ (no offset). All figures and tables use this corrected composite depth scheme.

\section{OXYGEN ISOTOPES}

The planktonic foraminifer $G$. bulloides was present in sufficient abundance for isotopic analysis in only about $20 \%$ (i.e., 65 ) of the 10 -mL Brunhes age samples processed at Rice University. In addition, no planktonic foraminifers were recovered from the Holocene section of Hole $798 \mathrm{C}$ (upper $2.5 \mathrm{~m}$ ). The $\delta^{18} \mathrm{O}$ results are shown in Figures 2 and 3. Isotopic stages 6,9-11, and 13-16 are not well defined because of the low sample density. We have assigned ages to the upper part of the composite Site 798 sequence based on isotope stage 4 and boundaries $6 / 7,7 / 8,11 / 12$, and $16 / 17$. Table 1 and Figure 4 summarize the faunal, paleomagnetic, radiocarbon, and isotopic age control used in this paper.

Glacial to interglacial $\Delta \delta^{18} \mathrm{O}$ is approximately $2 \%$ for stages $2-8$, the same as the planktonic $\delta^{18} \mathrm{O}$ shift at the $1 / 2$ boundary observed at Oki Ridge by Oba et al. (1980) and Oba (1984, 1987; Fig. 5 ) and about $0.5 \%$ greater than the $1 / 2$ shift observed in three cores collected off the Pacific coast of Honshu (Chinzei and Oba, 1986; Chinzei et al., 1987). Glacial/interglacial isotopic variability is smaller ( $~ 1 \%$ o to $1.5 \%$ ) below stage 8 at Site 798 . Stage 16 shows the greatest ${ }^{18} \mathrm{O}$ enrichment, consistent with previous observations from open ocean areas (SPECMAP stack, Imbrie et al., 1984).

The lowest $\delta^{18} \mathrm{O}$ value occurs at $3 \mathrm{mbsf}$. This isotopic excursion has been observed at 12 locations within the Japan Sea by Oba et al. (1980), Oba (1984, 1987), and Gorbarenko (1983, 1987) and occurs within the latter part of isotope stage 2 . The anomaly appears to be restricted to the Japan Sea and is attributed by Oba and Gorbarenko to freshening of Japan Sea surface waters. The precise timing of the event is not yet known. Oba (1987) presented two radiocarbon dates in core $\mathrm{C} 3$ from the Oki Ridge which place the peak of the low $\delta^{18} \mathrm{O}$ excursion at about 20 k.y. B.P. Derkachev et al.'s (1985) and Gorbarenko's (1987) radiocarbon data from core 1670 on the KitaYamato Bank place the $\delta^{18} \mathrm{O}$ minimum at about $15 \mathrm{k}$.y. B.P. In a recent review of the Japanese and Russian work, Keigwin and Gorbarenko (in press) concluded that the isotope anomalies in these two cores are in fact the same and that accelerator ${ }^{14} \mathrm{C}$ dates on picked foraminifers are needed to resolve its exact age. In this paper, for the purpose of age control we assign an age of $18 \pm 3$ k.y. B.P. (i.e., midway between the age assignments of Oba and Gorbarenko) to the $\delta^{18} \mathrm{O}$ low at 3 mbsf in Hole 798C.

The mechanism of surface-water freshening within the Japan Sea during late glacial time is not yet known. Oba (1987) and Chinzei and Oba (1986) postulated fresh-water input from the Huang Ho River during the glacial maximum, when the Japan Sea was largely isolated from exchange with the northwest Pacific as a result of the very shallow or emergent sills. Besides invoking lower sea level, this explanation also requires the active Huang Ho delta to deliver fresh water to the region of the Tsushima Strait during late glacial time. Keigwin and Gorbarenko (in press) suggested a similar role for the Amur River. They noted that while the Amur currently discharges into the Tatarsky Strait and primarily influences the Okhotsk Sea, a drainage shift during glacial time may have delivered fresh water to the nearly isolated Japan Sea Basin. In a summary of the Japanese and Russian isotope data, Gorbarenko (in press) and Keigwin and Gorbarenko (in press) examined the regional extent and magnitude of the

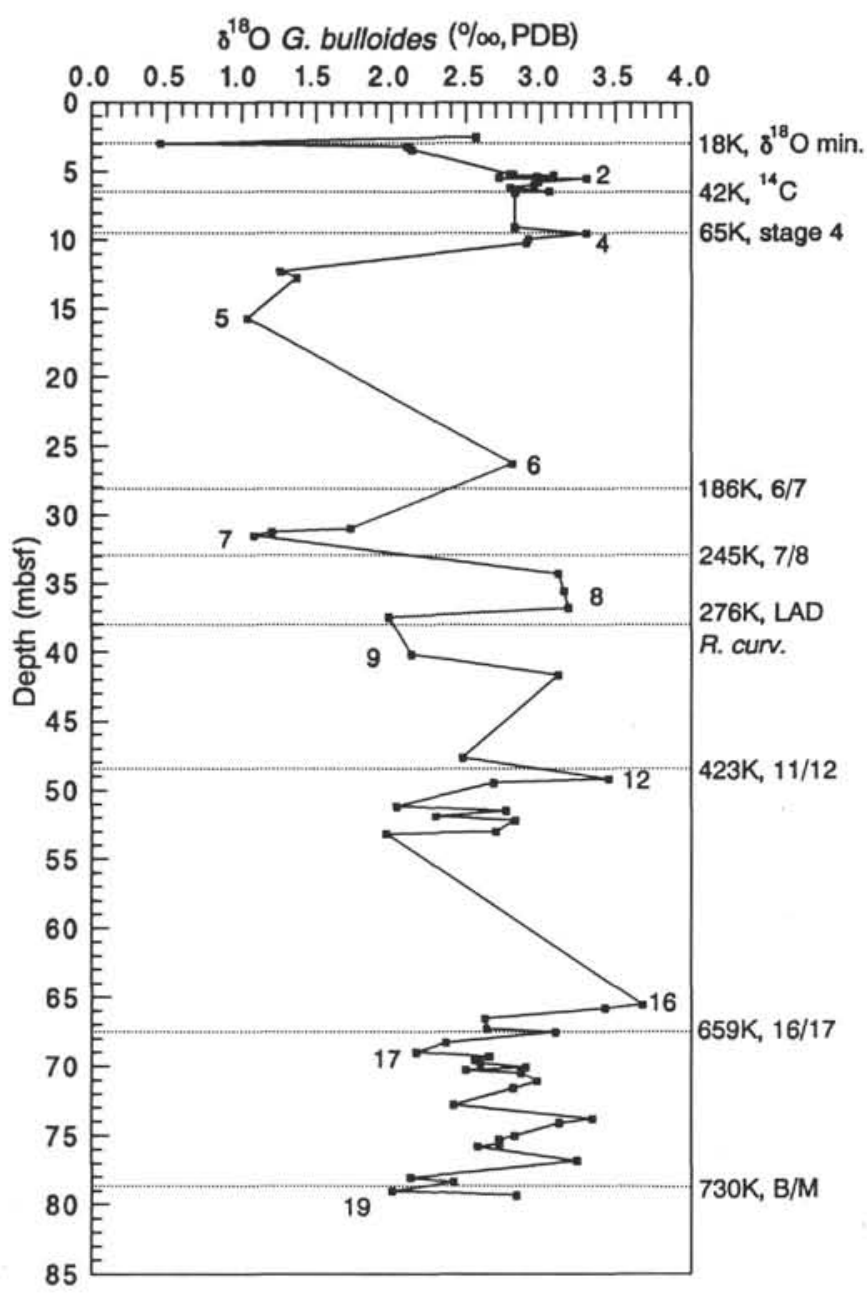

Figure 2. Oxygen isotopic composition of the planktonic foraminifer Globigerina bulloides in the upper $80 \mathrm{~m}$ at Site 798. Values are relative to the PDB isotopic standard. The numbers next to the curve are isotopic stage assignments. The horizontal lines show the age assignments listed in Table $1(\mathrm{~K}=$ k.y. B.P.). B/M = Brunhes/Matuyama paleomagnetic boundary.

low $\delta^{18} \mathrm{O}$ anomaly and concluded that the presently available data do not provide strong support for a single point source (e.g., river) of fresh water in the southern Japan Sea during glacial time. The absence of cores from the northern Japan Sea precludes assessment of a possible Amur River influence. As an alternative explanation, Gorbarenko (in press) suggested that surface-water freshening in the Japan Seamay have resulted from increased precipitation over evaporation in the region during glacial periods. Regardless of the precise cause, all authors linked surface-water freshening in the Japan Sea to the occurrence of laminated, organic-rich sediments depleted in benthic fauna. During times of lower surface-water salinity, the strong vertical mixing that characterizes the modern Japan Sea was reduced or absent, resulting in the development of dysaerobic bottom waters.

Stable isotope results from Site 798 may help constrain hypotheses about salinity variation within the Japan Sea and its influence on deep-water dysaerobia. Although our isotope curve is sparse within some intervals, we note that the $\delta^{18} \mathrm{O}$ anomaly at $3 \mathrm{mbsf}$ is the lightest value recorded throughout the Brunhes interval. Low $\delta^{18} \mathrm{O}$ values during isotope stages 5 and $7(\sim 1 \%$ ) are the same as those reported for planktonic foraminifers at the Oki Ridge during stage 1 by Oba (1984). Between stages 9 and $19, \delta^{18} \mathrm{O}$ minima are enriched in ${ }^{18} \mathrm{O}$ relative to those of the latest Pleistocene and average about $2 \%$. The $\delta^{18} \mathrm{O}$ of $G$. bulloides during glacial intervals $2,4,6$, and 8 is relatively 


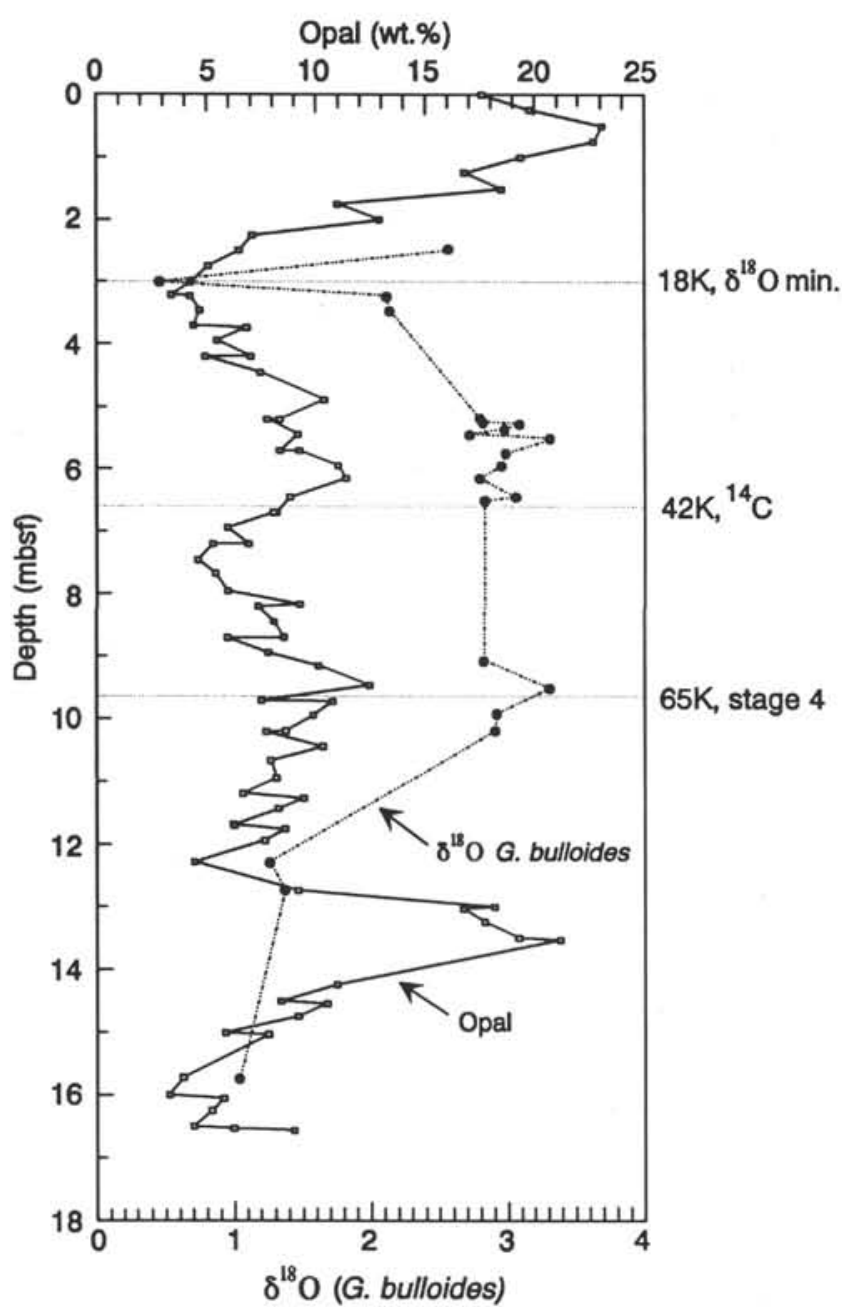

Figure 3. Biogenic opal and oxygen isotopic composition of the planktonic foraminifer Globigerina bulloides in the upper $17 \mathrm{~m}$ at Site 798. Isotopic values are in parts per mil relative to the PDB isotopic standard. The horizontal lines show age assignments listed in Table $1(\mathrm{~K}=\mathrm{k} . \mathrm{y}$. B.P.).

constant at $2.8 \%$ oo to $3.3 \%$. In summary, our stable isotope data, albeit limited, suggest that the $18 \pm 3$ k.y. BP. freshening event may have been unique within the late Pleistocene. If this is true, a physical mechanism not directly linked to rhythmic climate oscillations, such as emplacement of a sill or a river delta lobe shift during a sea-level minimum, is a more likely explanation for this event than a regional shift in evaporation/precipitation balance.

The $\delta^{18} \mathrm{O}$ values of the benthic foraminifer Uvigerina akitaensis are shown in Figure 6. Direct comparison with the $G$. bulloides data to examine changes in water column stratification is difficult because intervals with sufficient planktonic foraminifers for isotopic analysis are commonly devoid of benthic foraminifers. Glacial to interglacial $\Delta \delta^{18} \mathrm{O}$ is low, only about $0.6 \%$ oto $0.8 \%$, in the upper part of the record. Interestingly, during glacial stages 2 and 6 , benthic $\delta^{18} \mathrm{O}$ values are lower than during adjacent interglacials, opposite the general trend observed in $G$. bulloides. This implies that deep waters in the Japan Sea were warmer and/or less saline during at least part of the last two major glacial periods. In contrast, between stages 7 and 19 , benthic and planktonic $\delta^{18} \mathrm{O}$ values are subparallel and benthic $\delta^{18} \mathrm{O}$ variability increases to values typical of glacial/interglacial transitions recorded in benthic foraminifers from the North Pacific. The apparent transition at about $30 \mathrm{mbsf}$ is also marked by a change in abundance of benthic foraminifers. Sufficient Uvigerina akitaensis for isotopic analysis (8) were present in only $25 \%$ of our samples from

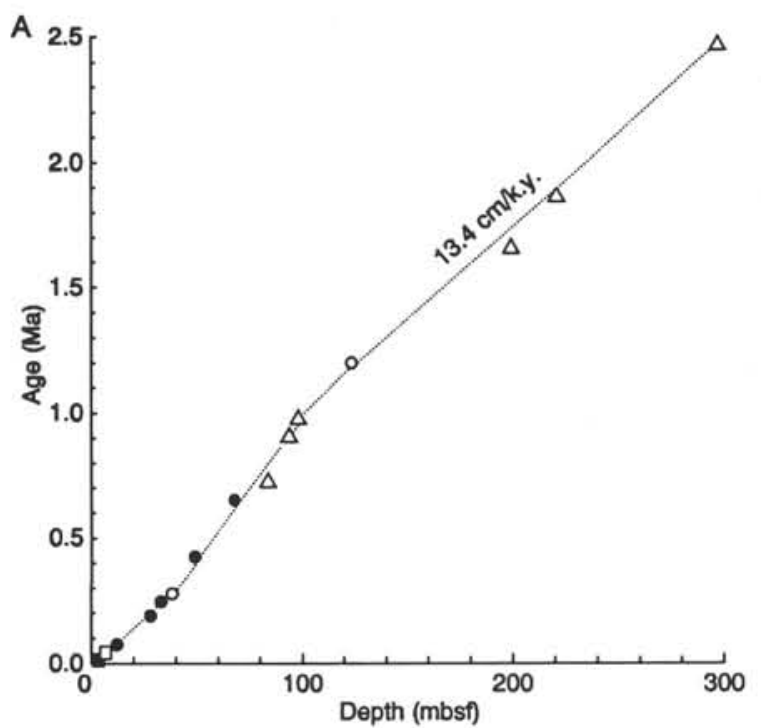

B

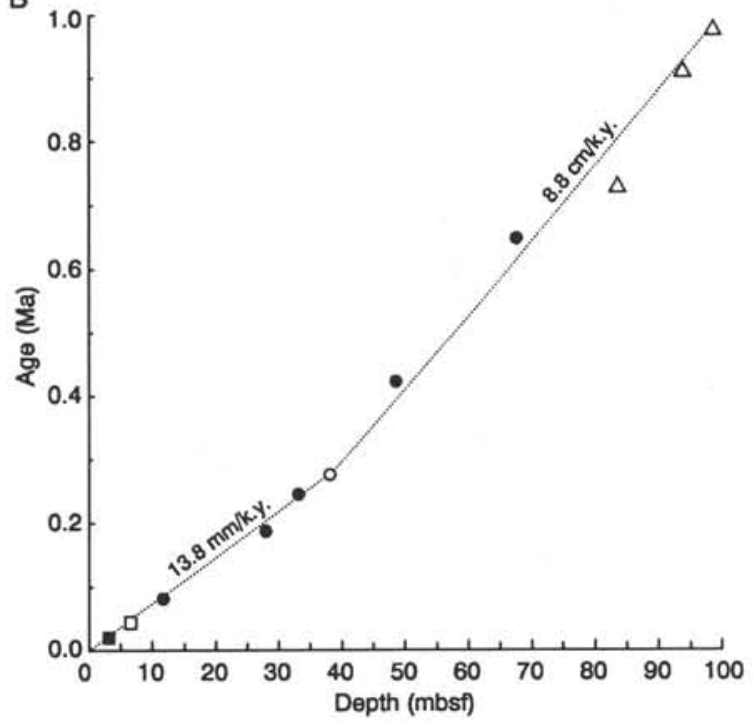

Figure 4. Age vs. depth for the composite stratigraphy presented in this paper, using the age assignments given in Table 1. A. Upper $300 \mathrm{~m}$. B. Upper $100 \mathrm{~m}$. Triangles are paleomagnetic datums; solid circles are isotopic stage boundaries from Figure 2; open circles are biostratigraphic datums; open square is accelerator radiocarbon date. Solid square is $\delta^{18} \mathrm{O}$ minimum at $18 \mathrm{k} . \mathrm{y}$. Linear regressions and sedimentation rates are for the three linear segments referred to in the text.

the upper part of the core. Below 30 mbsf sufficient benthic foraminifers were present in $>65 \%$ of the samples. Collectively, the foraminiferal isotopic and abundance data point toward periods of warm and/or less saline, stagnant deep waters during glacial lowstands of the past 200 k.y. Increased benthic foraminiferal abundance and positive covariance between benthic and planktonic isotope curves prior to 200 k.y. B.P. imply reduced stratification of the water column, possibly the result of more vigorous water exchange with the Pacific or enhanced deep-water production in the northern Japan Sea.

\section{OPAL CONTENT}

The combined opal content data set vs. depth is shown in Figure 7A. The transformation of depth to time (Fig. 7B) was accomplished using linear interpolation between the age assignments listed in 
Table 1. Age and depth assignments, Site 798.

\begin{tabular}{cccc}
\hline $\begin{array}{c}\text { Composite depth } \\
\text { (mbsf) }\end{array}$ & Hole & $\begin{array}{c}\text { Age } \\
(\text { Ma) }\end{array}$ & $\begin{array}{c}\text { Datum } \\
\text { level }\end{array}$ \\
\hline 3.02 & 0.018 & ${ }^{2}$ Lowest $\delta^{18} \mathrm{O}$ & $798 \mathrm{C}$ \\
6.56 & 0.042 & di4 $^{2} \mathrm{C}$ (wood) & $798 \mathrm{C}$ \\
9.5 & 0.065 & $\delta^{18} \mathrm{O} 4$ & $798 \mathrm{~A}$ \\
28.0 & 0.186 & $\delta^{18} \mathrm{O} 6 / 7$ & $798 \mathrm{~A}$ \\
33.0 & 0.245 & $\delta^{18} \mathrm{O} 7 / 8$ & $798 \mathrm{~A}$ \\
38.0 & 0.276 & LAD $R$. curvirostris & $798 \mathrm{~A}$ \\
48.5 & 0.423 & $\delta^{18} \mathrm{O} 11 / 12$ & $798 \mathrm{~A}$ \\
68.0 & 0.659 & $\delta^{18} \mathrm{O} 16 / 17$ & $798 \mathrm{~A}$ \\
80.5 & 0.73 & Brunhes/Matuyama & $798 \mathrm{C}$ \\
91.0 & 0.91 & Top Jaramillo & $798 \mathrm{C}$ \\
100.0 & 0.98 & Bottom Jaramillo & $798 \mathrm{C}$ \\
123.1 & 1.20 & LAD H. selii & $798 \mathrm{~A}$ \\
189.2 & 1.66 & Top Olduvai & $798 \mathrm{~B}$ \\
211.1 & 1.88 & Bottom Olduvai & $798 \mathrm{~B}$ \\
294.2 & 2.47 & Top Gauss & $798 \mathrm{~B}$ \\
\hline
\end{tabular}

"Isotope stage boundaries from this paper using ages from SPECMAP (Imbrie et al., 1984) below stage 4; other datums from Ingle, Suyehiro, von Breymann, et al. (1990).

${ }^{b}$ From Burckle et al. (chapter 34, this volume).

'From Oba (1984), Gorbarenko (1987), and Keigman and Gorbarenko (in press).

${ }^{\mathrm{d}}$ Date from 2-cm wood fragment recovered from Section 128 -

$798 \mathrm{C}-1 \mathrm{H}$ and analyzed at the University of Toronto accelerator dating facility (S. Scott, pers. comm., 1991).

KH79-3 L-3 \& C-3

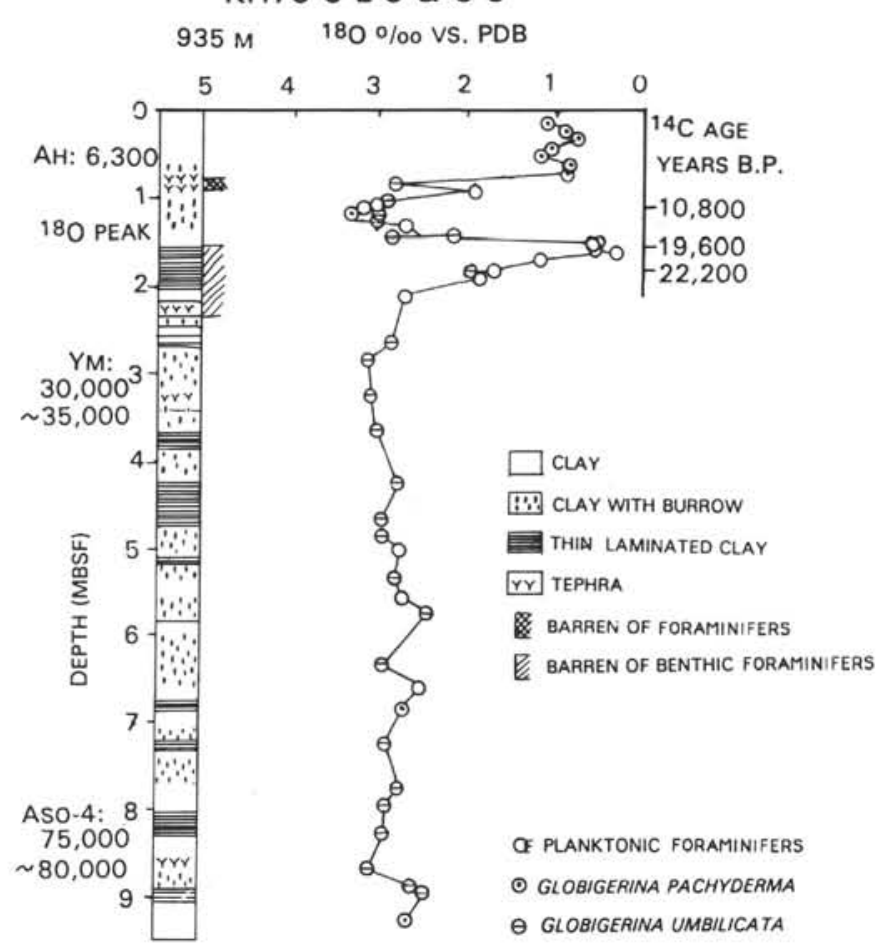

Figure 5. Composite oxygen isotopic stratigraphy of planktonic foraminifers from cores L3 and C 3 collected from the Oki Ridge. Carbon-14 ages listed on the right-hand side are from bulk-sediment calcium carbonate. Ah, Ym, and Aso-4 are major ash fall events used for correlation among Japan Sea cores. "Planktonic foraminifers" samples are mixtures of G. bulloides umbilicata and Neogloboquadrina pachyderma. From Oba (1984).

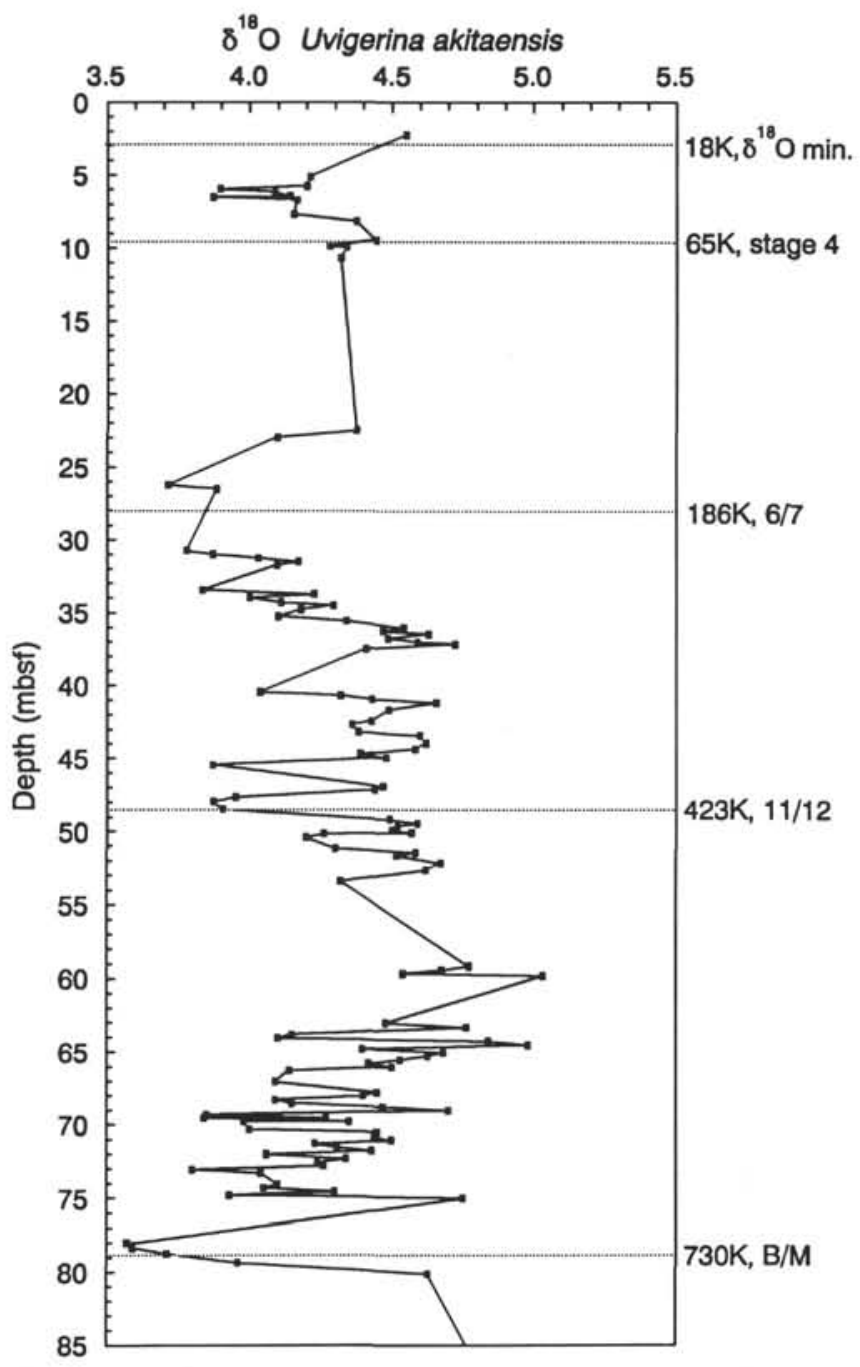

Figure 6. Oxygen isotopic composition of the benthic foraminifera Uvigerina akitaensis in the upper $80 \mathrm{~m}$ at Site 798. Values are parts per mil relative to the PDB isotopic standard. The horizontal lines show age assignments listed in Table 1 (K=k.y. B.P.).

Table 1. Based on shipboard smear slide observations, diatom tests are the dominant opaline component throughout the upper $350 \mathrm{~m}$; radiolarians and silicoflagellates make only minor contributions to the opal flux. Transformation of opal-A to opal-CT occurs at about $450 \mathrm{mbsf}$. The shallowest diagenetic dissolution of siliceous microfossils was observed at 380 mbsf, well below the deepest samples analyzed for weight percent opal.

Primary features of the opal record are a general increase in opal content with age and a cyclical variation between high and low values at a period of approximately $40 \mathrm{k} . y$. Opal contents are lowest between 0 and 750 k.y. B.P., ranging between $3 \%$ and $21 \%$ (average of $7.9 \%$ ). Opal contents are somewhat higher (average of $10.7 \%$ ) between 750 and 1300 k.y. B.P.; both minimum and maximum opal contents are several weight percent higher than in the upper interval. The most biosiliceous sequence occurs before 1300 k.y. B.P. where the average opal content is $20.1 \%$. Although opal minima within this interval remain low at $3 \%$ to $8 \%$, opal maxima reach values of $43 \mathrm{wt} \%$. 
A

Opal (wt. \%)

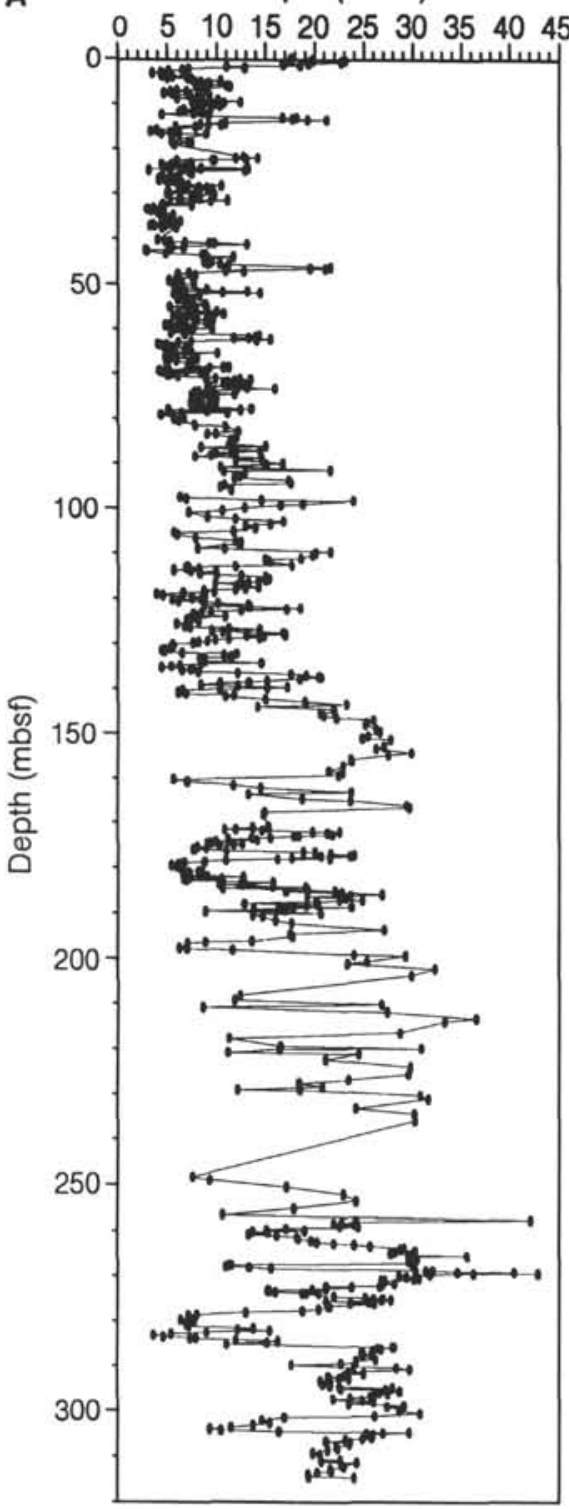

B

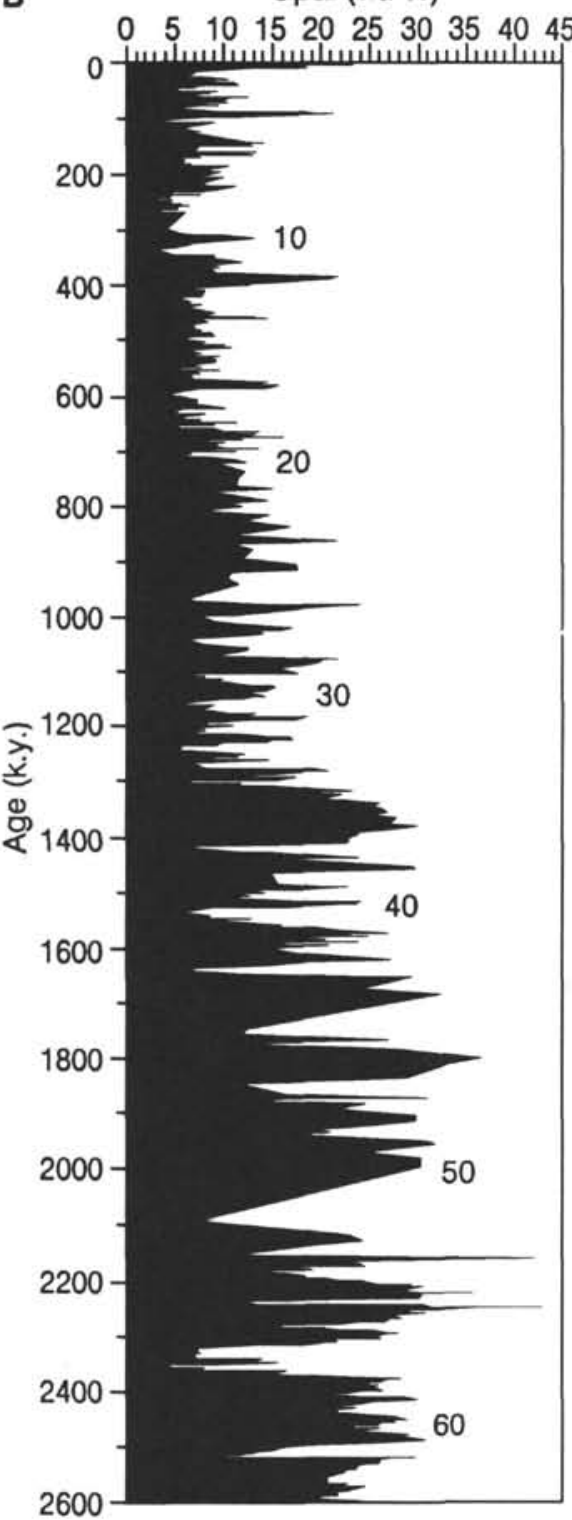

Figure 7. Weight percent biogenic opal vs. depth (A) and vs. time (B). Numbers in Figure 7B refer to the opal cycle number starting from the top of the composite sequence.

The only additional biogenic phase accumulating at this site is calcium carbonate. Based on shipboard analyses (Ingle, Suyehiro, von Breymann, et al., 1990) carbonate contents generally range from $0 \%$ to $10 \%$ above 30 mbsf ( 200 k.y. B.P.) and in the interval 140 to 210 mbsf ( 1300 to 1700 k.y. B.P.). Below 210 mbsf, $\mathrm{CaCO}_{3}$ is generally less than $1 \%$. Between 75 and 140 mbsf, the average $\mathrm{CaCO}_{3}$ content is less than $10 \%$ with maximum values of $15 \%$ to $20 \%$. Calcium carbonate content exceeds $20 \%$ in several samples from between 30 and 75 mbsf (maximum of $39 \%$ ). Reduced opal contents in this interval may result in part from dilution with biogenic carbonate. However, the relatively minor contribution of biogenic calcite throughout the remainder of the sequence would suggest that opal content variations, both short term (40-k.y. cycles) and long term, result from changes in the relative supply of terrigenous matter and biogenic silica.
Fifty-nine \pm 4 opal cycles occur above the Matuyama/Gauss paleomagnetic boundary at 294 mbsf yielding an average cycle thickness of $5.1 \pm 0.3 \mathrm{~m}$ and an average period of $41.8 \pm 2.6 \mathrm{k}$.y. Uncertainty in the number of cycles results from low cycle amplitude at several intervals as well as missing sections at some depths (e.g., 236 to 248 mbsf). Cycles are generally well defined throughout the record, particularly in the interval younger than 1300 k.y. B.P. Comparison with the G. bulloides $\delta^{18} \mathrm{O}$ data in the upper $17 \mathrm{~m}$ (Fig. 4) shows that although opal cycles are present throughout both glacial and interglacial periods, opal maxima are 2 to 2.5 times higher during interglacials. Although sparse isotopic data hamper the longer term comparison, this trend toward higher opal contents during interglacials appears characteristic of at least the past 700 k.y. Before 700 k.y. B.P., the variability of successive cycle maxima is reduced. Before 1300 k.y. B.P., there are several intervals of sustained high 
opal content (e.g., 1320 to 1450 k.y. B.P., 2400 to 2550 k.y. B.P.). Opal cycles are still apparent despite reduced amplitude, especially within the older interval. The extent to which the opal record reflects changes in silica production vs. input of terrigenous material can be addressed only via calculation of component accumulation rates.

\section{ACCUMULATION RATES}

Our age model, based on the combined paleomagnetic, isotopic, radiocarbon, and biostratigraphic datums in Table 1, can be subdivided into three linear segments (Fig. 4). We calculate average sedimentation rates of $13.8 \mathrm{~cm} / \mathrm{k} . \mathrm{y}$. between 0 and $38 \mathrm{mbsf}$ ( $\sim 0$ to $276 \mathrm{k} . \mathrm{y}$. B.P.), $8.8 \mathrm{~cm} / \mathrm{k} . y$. between 38 and $100 \mathrm{mbsf}$ ( 276 to 980 k.y. B.P.), and $13.4 \mathrm{~cm} / \mathrm{k}$.y. between 123 and $294 \mathrm{mbsf}(\sim 1200$ to $2470 \mathrm{k} . \mathrm{y}$. B.P.). Accumulation rates and sediment fluxes presented in Table 2 are calculated from the mean dry-bulk density, inorganic carbon, and organic carbon data in Ingle, Suyehiro, von Breymann, et al. (1990) and opal results from this paper.

Long-term average opal accumulation rates at Site 798 range from 0.6 to $1.8 \mathrm{~g} / \mathrm{cm}^{2} / \mathrm{k}$.y., values that are intermediate between opal fluxes reported for open-ocean high-fertility settings and Miocene-Holocene coastal upwelling systems. The average opal flux of $0.7 \mathrm{~g} / \mathrm{cm}^{2} / \mathrm{k}$.y. since 980 k.y. B.P. is approximately 15 times the average opal accumulation rate reported for the eastern equatorial Pacific during the same time interval by Rea et al. (1991). Opal accumulation rates during the late Pliocene/early Pleistocene at Site 798 average $1.8 \mathrm{~g} / \mathrm{cm}^{2} / \mathrm{k} . \mathrm{y}$., high compared with open-ocean values, but only $10 \%$ of the biosiliceous flux reported for rocks of the middle Miocene Onnagawa Formation of northern Japan by Tada (1991).

Increased opal flux appears to be more important than reduction in the supply of terrigenous debris in producing the opal-rich sediments that accumulated prior to 1300 k.y. B.P. Biosiliceous sedimentation within the Japan Sea must have decreased by at least $60 \%$ between 1300 and 980 k.y. B.P. Simultaneously, the accumulation rate of terrigenous materials decreased by no more than $25 \%$. Given the larger changes in opal flux relative to terrigenous flux that we observe in the long-term record, it is tempting to interpret the 41-k.y. cyclicity in a similar vein. However, our age control does not yet permit a rigorous calculation of component fluxes on such short time scales.

A rough analysis of sediment flux in the upper $10 \mathrm{~m}$ at Site 798 suggests that opal accumulation rates increase and terrigenous accumulation rates decrease during interglacial periods. In Table 2 we estimate a Holocene/latest glacial $(0-2.5 \mathrm{mbsf})$ opal flux of $1.3 \mathrm{~g} / \mathrm{cm}^{2} / \mathrm{k}$.y. at Site 798 and a glacial (stages $2-4,3-9.5 \mathrm{mbsf}$ ) opal flux of $0.7 \mathrm{~g} / \mathrm{cm}^{2} / \mathrm{k}$.y. This comparison is based on a limited number of shipboard sediment bulkdensity measurements and is dependent on the assumption that most of the Holocene section was recovered intact. We note that our calculated sedimentation rate of $16.7 \mathrm{~cm} / \mathrm{k} . \mathrm{y}$. for the upper $3 \mathrm{~m}$ is slightly higher than the late Pleistocene average of $13.8 \mathrm{~cm} / \mathrm{k} . \mathrm{y}$. and that we may have overestimated the Holocene accumulation rate by $15 \%$ to $20 \%$. Given the additional uncertainty regarding the age of the low $\delta^{18} \mathrm{O}$ anomaly at
3 mbsf, we assign an uncertainty of about $30 \%-35 \%$ to our flux estimates for the interval shallower than $9.5 \mathrm{mbsf}$.

\section{DISCUSSION}

A striking feature of the sedimentary sequence at Site 798 is the common occurrence of dark-light color rhythms throughout the upper Pliocene-Pleistocene section. Dark intervals tend to be homogeneous or laminated and are enriched in opal and organic matter and some, in biogenic carbonate. Light-colored intervals are commonly massive or bioturbated and are enriched in terrigenous debris. Föllmi et al. (this volume) described three different scales of dark-light rhythms. Secondorder rhythms comprise individual light and dark units that occur at scales of several centimeters to tens of centimeters. First-order rhythms consist of clusters of dark units followed by clusters of light-colored units and occur at scales of 4 to $6 \mathrm{~m}$. Bedding cycles approximately 5-6 m thick are also observed in logging data collected below $100 \mathrm{mbsf}$ at Site 798 by deMenocal et al. (this volume), who showed that they represent rhythmic changes in relative amounts of terrigenous and biosiliceous components. Föllmi et al. (this volume) and deMenocal et al. (this volume) demonstrated that variance in $\log$ data and sediment color is concentrated at periods of about 40 and 100 k.y., equivalent to the Milankovitch obliquity and eccentricity cycles.

The roughly $5-\mathrm{m}$ cyclicity we see in weight percent opal is clearly the same as the first-order bedding rhythmicity described previously. deMenocal et al. (this volume) directly linked gamma and resistivity $\log$ data to \%opal variations between 113 and 143 mbsf. Additionally, comparison of our opal data with the core photographs shows that high-opal intervals generally correspond with a greater abundance of second-order dark-colored units. Simple calculations using the number of opal cycles and estimated age show that rhythmicity in opal content at a period of about 41 k.y. extends throughout the entire 2600-k.y. record. Spectral analysis of our weight percent opal data shows broad peaks in variance centered at about $100,40,17,11$, and 6 k.y. Variance at periods of about 100 and 17 k.y. increases prior to about $1.3 \mathrm{Ma}$.

Second-order cycles occur at scales of tens of centimeters, roughly the same as our highest resolution sampling interval for the late Pleistocene. Intervals of dark, organic-rich, laminated sediments that are devoid of benthic foraminifers occur in the glacial-age portion of many piston cores from the Japan Sea (Miyake et al., 1968; Ujiie and Ichikura, 1973; Ichikura and Ujiie, 1976; Oba, 1983; Matoba, 1984) and are examples of one kind of second-order rhythm. These late glacial sediments have been interpreted as forming during periods of bottom-water stagnation following isolation of the Japan Sea during sea-level lowstands. Both freshening of surface waters (Oba, 1987) and expanded sea ice cover (Miyake et al., 1968) have been proposed as mechanisms for reducing vertical circulation.

From our Site 798 studies, it is apparent that clusters of dark, opaland organic carbon-rich sediments are not restricted to periods of lowest sea level during the Pleistocene. This implies that isolation of the Japan

Table 2. Accumulation rates, Site 798.

\begin{tabular}{|c|c|c|c|c|c|c|c|c|c|}
\hline $\begin{array}{l}\text { Depth } \\
\text { interval } \\
\text { (mbsf) }\end{array}$ & $\begin{array}{c}\text { Age } \\
\text { (k.y. BP.) }\end{array}$ & $\begin{array}{c}\text { Sedimentation } \\
\text { rate } \\
(\mathrm{cm} / \mathrm{k} . \mathrm{y} .)\end{array}$ & $\begin{array}{l}\text { Mean dry- } \\
\text { bulk density } \\
\left(\mathrm{g} / \mathrm{cm}^{3}\right)\end{array}$ & $\begin{array}{c}\text { Accumulation } \\
\text { rate } \\
\left(\mathrm{g} / \mathrm{cm}^{2} / \mathrm{k} . \mathrm{y} .\right)\end{array}$ & $\begin{array}{c}\text { Opal } \\
\text { (wt\%) }\end{array}$ & $\begin{array}{c}\text { Organic } \\
\text { matter } \\
(w t \%)\end{array}$ & $\begin{array}{c}\text { Calcium } \\
\text { carbonate } \\
\text { (wt\%) }\end{array}$ & $\begin{array}{c}\text { Opal } \\
\text { flux } \\
\left(\mathrm{g} / \mathrm{cm}^{2} / \mathrm{k} . \mathrm{y} .\right)\end{array}$ & $\begin{array}{c}\text { Terrigenous } \\
\text { flux } \\
\left(\mathrm{g} / \mathrm{cm}^{2} / \mathrm{k} . \mathrm{y} \text {. }\right)\end{array}$ \\
\hline $0-2.5$ & $0-15$ & 16.7 & 0,48 & 8.0 & 15.9 & 2.2 & 5.3 & 1.3 & 6.1 \\
\hline $3-9.5$ & $18-65$ & 13.8 & 0.67 & 9.3 & 7.4 & 2.9 & 9.9 & 0.7 & 7.4 \\
\hline $0-38$ & $0-276$ & 13.8 & 0.72 & 9.9 & 7.8 & 3.0 & 6.2 & 0.8 & 8.2 \\
\hline $38-100$ & $276-980$ & 8.8 & 0.79 & 6.9 & 8.8 & 3.9 & 13.1 & 0.6 & 5.1 \\
\hline $140-294$ & $1320-2470$ & 13.4 & 0.69 & 9.3 & 19.4 & 3.1 & 4.2 & 1.8 & 6.8 \\
\hline
\end{tabular}

Note: Ages are based on datums in Table 1. Sedimentation rates for $0-2.5 \mathrm{mbsf}$ are based on an assumed core-top age of $0 \mathrm{k} . \mathrm{y}$. BP. Organic matter is calculated at $1.7 \times$ organic carbon content. Terrigenous flux is calculated using terrigenous material $(w t \%)=100-(o p a l$ wt $\%+$ organic matter wt $\%$ + calcium carbonate wt\%). Mean dry-bulk density, carbon (organic matter), and calcium carbonate data from Ingle, Suyehiro, von Breymann, et al. (1990). 
Sea is not a prerequisite for deep-water stagnation. Likewise, surfacewater salinity variations do not appear to be a strong candidate for regulating deep-water dysaerobia throughout the Pleistocene. Our stable isotope data provide evidence for freshening of the Japan Sea only during glacial events of the last $200 \mathrm{k} . \mathrm{y}$. and significant freshening of surface waters at only one time, approximately 18 k.y. B.P. Deep-water dysaerobia in the Japan Sea may result primarily from periodic reductions in air-sea heat exchange in the northern Japan Sea, the present site of local deep-water production. Important variables governing heat exchange are often interdependent and include winter temperature, wind velocity, and extent of sea ice formation. Wind velocity is particularly important, especially in areas where sea ice may form and effectively insulate the water column unless broken up and carried away. By this scenario, deep waters would tend toward dysaerobia during periods of reduced heat exchange (e.g., warmer and/or less windy periods in the northern Japan Sea). This mechanism would be amplified by, but is not dependent on, surface-water freshening and isolation of the sea during lowstands.

We also note that high surface-water productivity is not necessarily linked to deep-water stagnation and preservation of organic material at depth. The highest opal contents in the upper $18 \mathrm{~m}$ of Site 798 occur during interglacial periods when sedimentary structures and organic carbon contents suggest well-ventilated bottom waters. $\mathrm{Nu}$ trient supply to Japan Sea surface waters may increase during sealevel highstands, when greater volumes of water enter the sea from the North Pacific. Alternatively, wind-induced coastal upwelling may regulate productivity in near coastal areas of the Japan Sea.

If nutrient supply from the Pacific regulates Japan Sea biosiliceous productivity, the decrease in opal flux at Site 798 at about 1.3 Ma may reflect a major step in the development of the modern sill system. Alternatively, this decrease may be linked to a major cooling step in the Northwest Pacific, as observed by Sancetta and Silvestri (1986) and Morley and Dworetzky (in press). Morley and Dworetzky (in press) noted that a distinct radiolarian faunal change at 1.2 to $1.3 \mathrm{Ma}$ at Deep Sea Drilling Project Site $580\left(41^{\circ} 37^{\prime} \mathrm{N}, 153^{\circ} 10^{\prime} \mathrm{E}\right)$ marks the first cooling in the North Pacific comparable in intensity to subsequent cool periods of the late Pleistocene.

Although the Pliocene through Holocene decrease in opal content is attributable mostly to reduced opal flux, the extent to which the 41-k.y. opal cycles reflect changes in biosiliceous production vs. terrigenous supply is not yet well defined. The fact that variance in opal content is concentrated within the obliquity frequency band for at least the last 2.6 m.y. suggests a mechanism not directly linked to sea level or temperature. Variation in regional atmospheric circulation is an obvious candidate. Periodic changes in wind regime would likely influence a variety of processes that regulate sedimentation in the Japan Sea: e.g., supply of aeolian dust from the loess fields of China (deMenocal et al., this volume), monsoonal control of water column overturn (Föllmi et al., this volume), and nutrient supply to surface waters either by local upwelling or importation via the Tsushima Current. Although our rough calculations suggest that opal fluxes have increased and terrigenous fluxes have decreased during the late glacial through Holocene at Site 798, this high-amplitude opal peak is not necessarily representative of most opal cycles of the Pleistocene. Resolution awaits better age control and detailed comparison of the opal data with sediment color and geochemical properties.

Quantitative opal flux measurements are not yet available at other drill sites in the Japan Sea. If opal fluxes at Site 798 are representative of the entire Japan Sea, we calculate basinwide Si removal rates of $0.09 \times 10^{14} \mathrm{~g} / \mathrm{yr}$ for the late Quaternary and $0.18 \times 10^{14} \mathrm{~g} / \mathrm{yr}$ for the period between 1.3 and $2.5 \mathrm{Ma}$, equivalent to removal of $1.5 \%$ and $3 \%$ of the annual supply of dissolved silica to the ocean (DeMaster, 1981).

\section{CONCLUSIONS}

1. Biogenic opal content varies between 3 and $43 \mathrm{wt} \%$ in the upper $320 \mathrm{~m}$ at Site 798 , an interval spanning the past $2.6 \mathrm{Ma}$. Variance is strongly concentrated at the 41-k.y. obliquity band throughout the entire record; variance at 17 and 100 k.y. increases before $1.3 \mathrm{Ma}$.

2. These 5-6-m cycles in opal content are equivalent to the first-order rhythms described by Föllmi et al. (this volume) that comprise clusters of dark-colored, typically laminated intervals alternating with light-colored massive or bioturbated units.

3. Opal fluxes are highest during the period between 1.3 and 2.6 Ma and decrease by a factor of 2 during the late Pleistocene, possibly the result of increasing tectonic isolation of the Japan Sea. Rough calculations suggest that opal fluxes increase and terrigenous fluxes decrease during the Holocene relative to the last glacial period. However, our age control is not yet sufficient to allow an unambiguous assessment of the relative influence of biosiliceous production vs. terrigenous input in producing the 41-k.y. variation in opal content. If Site 798 is representative of the entire Japan Sea, this marginal basin, comprising $0.27 \%$ of the world's seafloor, may have accounted for the removal of $1.5 \%$ to $3 \%$ of the Si supply to ocean during the latest Neogene.

4. Although our data density is sparse because of low foraminifer abundance in some intervals, stable isotope results indicate that significant freshening of Japan Sea waters at 15 to 21 k.y. B.P. may have been a unique event during the late Pleistocene. During parts of glacial stages 2 and 6 benthic foraminifer $\delta^{18} \mathrm{O}$ values are lighter than during adjacent interglacials, suggesting unusual warming and/or freshening of deep waters. Collectively, the stable isotope and \%opal data are consistent with continuing isolation of the Japan Sea during the Quaternary.

5. Complex relationships between the stable isotope results, \%opal data, and sediment characteristics such as color and organic and inorganic carbon content preclude development of a simple model to explain cyclical sedimentation. Opal maxima occur within both light and dark intervals and the processes that control surface-water productivity are at times decoupled from the factors that regulate deepwater dysaerobia. We suggest that water column overturn is controlled largely by regional atmospheric circulation, which must also have an as yet poorly understood effect on surface-water fertility.

\section{ACKNOWLEDGMENTS}

This work was supported by USSAC grants to R. B. Dunbar, L. H. Burckle, and P. B. deMenocal. We thank John Barron, Lloyd Keigwin, and Brad Linsley for comments on the manuscript. Dave Mucciarone, Bill Jones, Jennifer Rogers, and Kate McPartlin assisted with sample preparation and opal and isotopic analysis at Rice University.

\section{REFERENCES}

Akiba, F., 1986. Middle Miocene to Quaternary diatom biostratigraphy in the Nankai Trough and Japan Trench, and modified lower Miocene through Quaternary diatom zones for the middle-to-high latitudes of the North Pacific. In Kagami, H., Karig, D. E., and Coulbourn, W. T., et al., Init. Repts. DSDP, 87: Washington (U.S. Govt. Printing Office), 393-481.

Baldauf, J. G., 1986. Diatom biostratigraphic and paleoceanographic interpretations for the middle and high latitude North Atlantic Ocean. In Summerhayes, C. P., and Shackleton, N. J. (Eds.), North Atlantic Paleoceanography, Geol. Soc. Spec. Publ. London, 21:243-252.

Barron, J. A., 1981. Late Cenozoic diatom biostratigraphy and paleoceanography of the middle-latitude eastern North Pacific, Deep Sea Drilling Project Leg 63. In Yeats, R. S., Haq, B. U., et al., Init. Repts. DSDP, 63: Washington (U.S. Govt. Printing Office), 507-538. 
1985. Diatom paleoceanography and paleoclimatology of the central and eastern equatorial Pacific between 18 and 6.2 Ma. In Mayer, L., Theyer, F., Thomas, E., et al., Init. Repts. DSDP, 85: Washington (U.S. Govt. Printing Office), 935-945.

, 1986. Paleoceanographic and tectonic controls on deposition of the Monterey Formation and related siliceous rocks in California. Palaeogeogr., Palaeoclimatol., Palaeoecol., 53:27-45.

Barron, J. A., and Baldauf, J. G., 1989. Tertiary cooling steps and paleoproductivity as reflected by diatoms and biosiliceous sediments. In Berger, W. H., Smetacek, V. S., and Wefer, G. (Eds.), Productivity of the Ocean: Present and Past, Dahlem Workshop Reports, Life Res. Rep., 44:341-354. 1990. Development of biosiliceous sedimentation in the North Pacific during the Miocene and early Pliocene. In Tsuchi, R. (Ed.), Pacific Neogene Events: Their Timing, Nature and Interrelationship: Tokyo (Univ. of Tokyo Press), 43-63.

Brewster, N. A., 1980. Cenozoic biogenic silica sedimentation in the Antarctic Ocean. Geol. Soc. Am. Bull., 91:337-347.

Chinzei, K., 1978. Neogene molluscan faunas in the Japanese Islands: an ecologic and zoogeographic synthesis. Veliger, 21:155-170.

Chinzei, K., Fujioka, K., Kitazato, H., Koizumi, I., Oba, T., Oda, M., Okada, H., Sakai, T., and Tanimura, Y., 1987. Postglacial environmental change of the Pacific Ocean off the coasts of Central Japan. Mar. Micropaleontol. 11:273-291.

Chinzei, K., and Oba, T., 1986. Oxygen isotope studies of the deep sea sediments around Japan. Rec. Prog. Nat. Sci. Jpn., Quat. Res., 11:35-43.

DeMaster, D. J., 1981. The supply and accumulation of silica in the marine environment. Geochim. Cosmoschim. Acta, 45:1715-1732.

Derkachev, N. N., Utkin, I. V., Gorbarenko, S. A., et al., 1985. Correlation and accumulation rate of sediments of the Japan Sea during and after late-glacial time. Pac. Ocean Geol., N4:22-29.

Gorbarenko, S. A., 1983. Paleoceanographic conditions in the central part of the Sea of Japan during Holocene and late Pleistocene from data on ${ }^{18} \mathrm{O} /{ }^{16} \mathrm{O}$ in foraminiferal tests. Oceanology, 23:300-303.

, 1987. Paleogeography of the Japan Sea in the upper Pleistocene and Holocene. Izvest. Geogr. Ser., 6:106-113.

- in press. Stratigraphy and late Quaternary sediments in seas of Japan and Okhotsk and their paleoceanological conditions. In Geology and Geophysics of the Japan Sea. Jpn.-USSR Monogr. Ser., 1.

Hidaka, K., 1966. Japan Sea. In Fairbridge, R. (Ed.), Encyclopedia of Oceanography: New York (Reinhold), 417-424.

Ichikura, M., and Ujiie, H., 1976. Lithology and planktonic foraminifera of the Sea of Japan piston cores. Bull. Nat. Sci. Mus., Ser. C (Geology), 2:151-177.

Imbrie, J., Hays, J. D., Martinson, D. G., McIntyre, A., Mix, A. C., Morley, J. J., Pisias, N. G., Prell, W. L., and Shackleton, N. J., 1984. The orbital theory of Pleistocene climate: support from a revised chronology of the marine $\delta^{18} \mathrm{O}$ record. In Berger, A. L., Imbrie, J., Hays, J., Kukla, G., and Saltzman, B. (Eds.), Milankovitch and Climate: Dordrecht (D. Riedel), 269-305.

Ingle, J. C., Jr., 1973. Summary comments on Neogene biostratigraphy, physical stratigraphy, and paleo-oceanography in the marginal northeastern Pacific Ocean. In Kulm, L. D., von Huene, R., et al., Init. Repts. DSDP, 18: Washington (U. S. Govt. Printing Office), 949-960.

1981. Origin of Neogene diatomites around the North Pacific rim. In Garrison, R. E., Douglas, R. G., Pisciotto, K., Isaacs, C., and Ingle, J. C. (Eds.), The Monterey Formation and Related Siliceous Rocks of California. Spec. Publ.-Pacific Section Soc. Econ. Paleontol. Mineral., $159-179$.

Ingle, J. C., Jr., Suyehiro, K., von Breymann, M. T., et al., 1990. Proc. ODP, Init. Repts., 128: College Station, TX (Ocean Drilling Program).

Isaacs, C. M., 1985. Abundance versus rates of accumulation in fine-grained strata of the Miocene Santa Barbara Basin, California. Geo-Mar. Lett. $5: 25-30$
Keigwin, L. D., and Gorbarenko, S. A., in press. Influence of sea level change on the Japan Sea and possible consequences for the northwest Pacific Ocean. Quat. Res.

Leinen, M., 1979. Biogenic silica accumulation in the central equatorial Pacific and its implications for Cenozoic paleoceanography. Geol. Soc. Am. Bull., 90:1310-1376.

Matoba, Y., 1984. Paleoenvironments of the Sea of Japan. In Oertli, H. J. (Ed.), Benthos '83: 2nd Inter. Symp. on Benthic Foraminifera, Elf-Aquitane, $409-414$.

Miyake, S., Sugimura, Y., and Matsumoto, E., 1968. Ionium-thorium chronology of the Japan Sea cores. Recent Oceanog. Works Jpn., 9:189-195.

Morley, J. J., and Dworetzky, B. A., in press. Evolving Pliocene-Pleistocene climate: a North Pacific perspective. Quat. Sci. Rev., 10:225-237.

Mortlock, R. A., and Froelich, P. N., 1989. A simple method for the rapid determination of biogenic opal in pelagic marine sediments. Deep-Sea Res. Part A, 36:1415-1426.

Niino, H., Emery, K. O., and Kim, C. M., 1969. Organic carbon in sediments of the Japan Sea. J. Sediment. Petrol., 39:1390-1398.

Oba, T., 1983. Paleoenvironment of the Japan Sea since the last glacial age. Gekkan Chikyu, 5:37-46.

1984. Oxygen and carbon isotope analyses in the cores KH79-3C3, the Japan Sea, since the last glacial age. Gekkan Chikyu, 6:558-575. , 1987. Upper Pleistocene of the Japan Sea floor. Quat. Res., 25:319-321.

Oba, T., Horibe, Y., and Kitazato, H., 1980. Analysis of the paleoenvironment since the last glacial age based on two cores from the Japan Sea. Arch. Nat. Sci., 13:31-49.

Pisciotto, K. A., and Garrison, R. E., 1981. Lithofacies and depositional environments of the Monterey Formation, California. In Garrison, R. E., and Douglas, R. G. (Eds.), The Monterey Formation and Related Siliceous Rocks of California. Spec. Publ.-Pacific Sec. Soc. Econ. Paleontol. Mineral., 97-122.

Rea, D. K., Pisias, N. G., and Newberry, T., 1991. Late Pleistocene paleoclimatology of the central equatorial Pacific: flux patterns of biogenic sediments. Paleoceanography, 6:227-244.

Sancetta, C., and Silvestri, S., 1986. Pliocene-Pleistocene evolution of the North Pacific ocean-atmosphere system, interpreted from fossil diatoms. Paleoceanography, 1:163-180.

Tada, R., 1991. Origin of rhythmical bedding in middle Miocene siliceous rocks of the Onnagawa Formation, northern Japan. J. Sediment. Petrol., 61:1123-1145.

Tamaki, K., 1988. Geological structure of the Japan Sea and its tectonic implications. Chishitsu Chosasho Geppo, 39:269-365.

Tamaki, K., Pisciotto, K., Allan, J., et al., 1990. Proc. ODP, Init. Repts., 127: College Station, TX (Ocean Drilling Program).

Ujiie, H., and Ichikura, M., 1973. Holocene to uppermost Pleistocene planktonic foraminifers in a piston core from off San'n district, Sea of Japan. Trans. Proc. Paleontol. Soc. Jpn., 91:137-150.

Yasui, M., Yasuoka, T., Tanioka, K., and Shiota, O., 1967. Oceanographic studies of the Japan Sea (1) water characteristics. Oceanograph. Mag., 19:177-192.

Date of initial receipt: 10 May 1991

Date of acceptance: 27 November 1991

Ms $127 / 128 B-147$ 
APPENDIX

Biogenic Opal, Site 798.

\begin{tabular}{|c|c|c|}
\hline $\begin{array}{l}\text { Depth } \\
\text { (mbsf) }\end{array}$ & $\begin{array}{l}\text { Opal } \\
(w t \%)\end{array}$ & Source ${ }^{a}$ \\
\hline 0.01 & 17.6 & RiceC \\
\hline 0.25 & 19.8 & RiceC \\
\hline 0.50 & 23.1 & RiceC \\
\hline 0.75 & 22.7 & RiceC \\
\hline 1.00 & 19.4 & RiceC \\
\hline 1.25 & 16.8 & RiceC \\
\hline 1.51 & 18.5 & RiceC \\
\hline 1.75 & 11.0 & RiceC \\
\hline 2.00 & 12.9 & RiceC \\
\hline 2.25 & 7.1 & RiceC \\
\hline 2.50 & 6.5 & RiceC \\
\hline 2.75 & 5.1 & RiceC \\
\hline 3.01 & 4.3 & RiceC \\
\hline 3.21 & 3.4 & Burckle \\
\hline 3.23 & 4.3 & Rice \\
\hline 3.46 & 4.7 & Rice \\
\hline 3.70 & 4.4 & Burckle \\
\hline 3.74 & 6.9 & Rice \\
\hline 3.94 & 5.5 & Rice \\
\hline 4.20 & 7.0 & Rice \\
\hline 4.20 & 5.0 & Burckle \\
\hline 4.45 & 7.5 & Rice \\
\hline 4.89 & 10.4 & Rice \\
\hline 5.20 & 8.4 & Rice \\
\hline 5.20 & 7.8 & Burckle \\
\hline 5.44 & 9.2 & Rice \\
\hline 5.70 & 8.4 & Rice \\
\hline 5.70 & 9.3 & Burckle \\
\hline 5.95 & 11.0 & Rice \\
\hline 6.15 & 11.4 & Rice \\
\hline 6.45 & 8.8 & Rice \\
\hline 6.70 & 8.2 & Rice \\
\hline 6.70 & 8.1 & Burckle \\
\hline 6.94 & 6.0 & Rice \\
\hline 7.20 & 6.9 & Rice \\
\hline 7.20 & 5.3 & Burckle \\
\hline 7.45 & 4.6 & Rice \\
\hline 7.67 & 5.4 & Rice \\
\hline 7.95 & 6.0 & Rice \\
\hline 8.16 & 9.3 & Rice \\
\hline 8.20 & 7.3 & Burckle \\
\hline 8.44 & 8.1 & Rice \\
\hline 8.69 & 8.5 & Rice \\
\hline 8.70 & 6.0 & Burckle \\
\hline 8.94 & 7.8 & Rice \\
\hline 9.16 & 10.1 & Rice \\
\hline 9.46 & 12.5 & Rice \\
\hline 9.70 & 7.5 & Burckle \\
\hline 9.72 & 10.8 & Rice \\
\hline 9.94 & 9.9 & Rice \\
\hline 10.19 & 8.6 & Rice \\
\hline 10.20 & 7.7 & Burckle \\
\hline 10.44 & 10.3 & Rice \\
\hline 10.67 & 7.9 & Rice \\
\hline 10.95 & 8.2 & Rice \\
\hline 11.20 & 6.7 & Burckle \\
\hline 11.27 & 9.4 & Rice \\
\hline 11.44 & 8.3 & Rice \\
\hline 11.69 & 6.2 & Rice \\
\hline 11.70 & 6.3 & Burckle \\
\hline 11.76 & 8.6 & Burckle \\
\hline 11.94 & 7.7 & Rice \\
\hline 12.28 & 4.5 & Rice \\
\hline 12.73 & 9.2 & Rice \\
\hline 13.00 & 18.2 & Burckle \\
\hline 13.03 & 16.7 & Rice \\
\hline 13.24 & 17.7 & Rice \\
\hline 13.50 & 19.3 & Burckle \\
\hline 13.53 & 21.2 & Rice \\
\hline 14.24 & 10.9 & Rice \\
\hline 14.50 & 8.4 & Burckle \\
\hline 14.54 & 10.5 & Rice \\
\hline 14.75 & 9.2 & Rice \\
\hline 15.00 & 5.9 & Burckle \\
\hline
\end{tabular}

Appendix (continued).

\begin{tabular}{|c|c|c|}
\hline $\begin{array}{l}\text { Depth } \\
\text { (mbsf) }\end{array}$ & $\begin{array}{c}\text { Opal } \\
\text { (wt\%) }\end{array}$ & Source ${ }^{a}$ \\
\hline 15.03 & 7.8 & Rice \\
\hline 15.72 & 3.9 & Rice \\
\hline 16.00 & 3.3 & Burckle \\
\hline 16.05 & 5.8 & Rice \\
\hline 16.24 & 5.3 & Rice \\
\hline 16.50 & 4.4 & Burckle \\
\hline 16.53 & 6.2 & Rice \\
\hline 16.56 & 9.0 & Burckle \\
\hline 18.18 & 5.4 & RiceB \\
\hline 18.34 & 7.1 & RiceB \\
\hline 18.50 & 7.5 & RiceB \\
\hline 18.73 & 5.6 & RiceB \\
\hline 18.90 & 5.7 & RiceB \\
\hline 21.75 & 12.7 & Rice \\
\hline 21.99 & 14.2 & Rice \\
\hline 22.00 & 11.9 & Burckle \\
\hline 22.24 & 13.0 & Rice \\
\hline 22.49 & 9.8 & Rice \\
\hline 22.50 & 9.6 & Burckle \\
\hline 22.56 & 5.9 & Burckle \\
\hline 22.98 & 7.4 & Rice \\
\hline 23.24 & 7.0 & Rice \\
\hline 23.49 & 5.3 & Rice \\
\hline 23.50 & 4.4 & Burckle \\
\hline 23.75 & 7.5 & Rice \\
\hline 23.99 & 5.0 & Rice \\
\hline 24.00 & 4.5 & Burckle \\
\hline 24.24 & 8.4 & Rice \\
\hline 24.48 & 13.2 & Rice \\
\hline 24.60 & 3.1 & Burckle \\
\hline 24.74 & 12.9 & Rice \\
\hline 24.99 & 7.4 & Rice \\
\hline 25.00 & 6.3 & Burckle \\
\hline 25.24 & 7.2 & Rice \\
\hline 25.49 & 7.5 & Rice \\
\hline 25.50 & 5.2 & Burckle \\
\hline 25.97 & 4.4 & Burckle \\
\hline 26.24 & 6.0 & Rice \\
\hline 26.49 & 4.1 & Rice \\
\hline 26.50 & 4.1 & Burckle \\
\hline 26.74 & 6.0 & Rice \\
\hline 26.99 & 5.3 & Rice \\
\hline 27.00 & 4.1 & Burckle \\
\hline 27.07 & 4.8 & Burckle \\
\hline 27.24 & 5.7 & Rice \\
\hline 27.48 & 6.4 & Rice \\
\hline 27.74 & 6.2 & Rice \\
\hline 28.00 & 7.1 & Burckle \\
\hline 28.24 & 10.5 & Rice \\
\hline 28.49 & 8.2 & Rice \\
\hline 28.50 & 6.7 & Burckle \\
\hline 28.56 & 6.1 & Burckle \\
\hline 28.74 & 9.0 & Rice \\
\hline 28.98 & 9.5 & Rice \\
\hline 29.24 & 8.2 & Rice \\
\hline 29.50 & 5.0 & Burckle \\
\hline 29.55 & 5.1 & Rice \\
\hline 29.74 & 7.9 & Rice \\
\hline 30.00 & 4.9 & Burckle \\
\hline 30.06 & 9.8 & Burckle \\
\hline 30.75 & 7.4 & Rice \\
\hline 31.00 & 8.3 & Rice \\
\hline 31.00 & 5.2 & Burckle \\
\hline 31.24 & 6.3 & Rice \\
\hline 31.50 & 6.1 & Rice \\
\hline 31.50 & 11.1 & Burckle \\
\hline 31.74 & 9.4 & Rice \\
\hline 32.02 & 7.5 & Rice \\
\hline 32.25 & 4.5 & Rice \\
\hline 32.50 & 4.6 & Rice \\
\hline 32.50 & 7.5 & Burckle \\
\hline 32.80 & 4.4 & Rice \\
\hline 32.99 & 4.4 & Rice \\
\hline 33.00 & 4.4 & Burckle \\
\hline
\end{tabular}


Appendix (continued).

\begin{tabular}{|c|c|c|}
\hline $\begin{array}{l}\text { Depth } \\
\text { (mbsf) }\end{array}$ & $\begin{array}{c}\text { Opal } \\
\text { (wt\%) }\end{array}$ & Source ${ }^{a}$ \\
\hline 33.25 & 3.6 & Rice \\
\hline 33.46 & 2.9 & Rice \\
\hline 33.75 & 3.3 & Rice \\
\hline 33.98 & 3.9 & Rice \\
\hline 34.00 & 4.5 & Burckle \\
\hline 34.29 & 4.6 & Rice \\
\hline 34.49 & 4.3 & Rice \\
\hline 34.50 & 4.2 & Burckle \\
\hline 34.77 & 5.6 & Rice \\
\hline 35.24 & 5.6 & Rice \\
\hline 35.50 & 5.2 & Burckle \\
\hline 35.55 & 4.6 & Rice \\
\hline 36.00 & 6.3 & Burckle \\
\hline 36.06 & 5.3 & Rice \\
\hline 36.26 & 5.2 & Rice \\
\hline 36.45 & 4.4 & Rice \\
\hline 36.76 & 3.6 & Rice \\
\hline 37.00 & 3.2 & Rice \\
\hline 37.00 & 4.8 & Burckle \\
\hline 37.14 & 3.6 & Rice \\
\hline 37.48 & 4.5 & Rice \\
\hline 37.50 & 5.9 & Burckle \\
\hline 40.16 & 4.0 & Rice \\
\hline 40.40 & 5.2 & Burckle \\
\hline 40.43 & 4.7 & Rice \\
\hline 40.66 & 6.8 & Rice \\
\hline 40.90 & 9.2 & Burckle \\
\hline 40.92 & 9.8 & Rice \\
\hline 41.15 & 13.1 & Rice \\
\hline 41.64 & 5.5 & Rice \\
\hline 41.90 & 6.7 & Burckle \\
\hline 42.40 & 5.1 & Burckle \\
\hline 42.42 & 2.8 & Rice \\
\hline 42.65 & 2.9 & Rice \\
\hline 43.15 & 4.8 & Rice \\
\hline 43.40 & 8.6 & Burckle \\
\hline 43.42 & 8.9 & Rice \\
\hline 43.90 & 8.9 & Burckle \\
\hline 43.92 & 11.7 & Rice \\
\hline 44.35 & 9.2 & Rice \\
\hline 44.66 & 9.0 & Rice \\
\hline 44.90 & 9.5 & Burckle \\
\hline 44.94 & 8.7 & Rice \\
\hline 45.40 & 9.2 & Burckle \\
\hline 45.42 & 10.3 & Rice \\
\hline 45.65 & 11.2 & Rice \\
\hline 46.15 & 21.6 & Rice \\
\hline 46.40 & 19.5 & Burckle \\
\hline 46.48 & 21.1 & Rice \\
\hline 46.92 & 10.9 & Rice \\
\hline 47.15 & 12.8 & Rice \\
\hline 47.40 & 7.2 & Burckle \\
\hline 47.65 & 6.1 & Rice \\
\hline 47.95 & 7.9 & Rice \\
\hline 48.46 & 7.6 & Rice \\
\hline 48.65 & 5.9 & Rice \\
\hline 49.16 & 5.2 & Rice \\
\hline 49.43 & 6.5 & Rice \\
\hline 49.65 & 6.4 & Rice \\
\hline 49.90 & 6.2 & Rice \\
\hline 49.90 & 7.7 & Burckle \\
\hline 50.09 & 5.6 & Rice \\
\hline 50.15 & 6.2 & Rice \\
\hline 50.37 & 6.1 & Rice \\
\hline 51.15 & 9.0 & Rice \\
\hline 51.40 & 6.7 & Burckle \\
\hline 51.45 & 6.1 & Rice \\
\hline 51.65 & 13.1 & Rice \\
\hline 51.84 & 10.6 & Rice \\
\hline 51.90 & 14.4 & Burckle \\
\hline 52.15 & 5.6 & Rice \\
\hline 52.63 & 8.2 & Rice \\
\hline 52.90 & 6.5 & Burckle \\
\hline 52.96 & 6.5 & Rice \\
\hline 53.15 & 6.9 & Rice \\
\hline
\end{tabular}

Appendix (continued).

\begin{tabular}{|c|c|c|}
\hline $\begin{array}{l}\text { Depth } \\
\text { (mbsf) }\end{array}$ & $\begin{array}{c}\text { Opal } \\
\text { (wt\%) }\end{array}$ & Source ${ }^{a}$ \\
\hline 53.37 & 6.0 & Rice \\
\hline 53.40 & 6.1 & Burckle \\
\hline 53.75 & 7.6 & Rice \\
\hline 54.15 & 7.5 & Rice \\
\hline 54.39 & 7.3 & Rice \\
\hline 54.40 & 8.7 & Burckle \\
\hline 54.70 & 8.9 & Rice \\
\hline 54.90 & 6.7 & Burckle \\
\hline 55.10 & 5.2 & Rice \\
\hline 55.66 & 7.9 & Rice \\
\hline 55.90 & 7.0 & Burckle \\
\hline 55.93 & 9.1 & Rice \\
\hline 56.15 & 10.0 & Rice \\
\hline 56.40 & 7.9 & Rice \\
\hline 56.40 & 6.1 & Burckle \\
\hline 56.65 & 10.7 & Rice \\
\hline 56.90 & 5.5 & Burckle \\
\hline 57.12 & 7.6 & Rice \\
\hline 57.40 & 6.2 & Burckle \\
\hline 57.62 & 6.9 & Rice \\
\hline 57.90 & 9.6 & Rice \\
\hline 57.90 & 8.0 & Burckle \\
\hline 58.19 & 8.8 & Rice \\
\hline 58.35 & 9.2 & Rice \\
\hline 58.65 & 9.2 & Rice \\
\hline 58.90 & 6.6 & Burckle \\
\hline 58.91 & 6.1 & Rice \\
\hline 59.00 & 5.2 & Burckle \\
\hline 59.14 & 4.7 & Rice \\
\hline 59.33 & 6.7 & Rice \\
\hline 59.40 & 6.4 & Burckle \\
\hline 59.42 & 7.7 & Rice \\
\hline 59.66 & 5.6 & Rice \\
\hline 59.80 & 5.3 & Rice \\
\hline 59.90 & 9.5 & Rice \\
\hline 59.90 & 6.5 & Burckle \\
\hline 60.28 & 7.5 & Rice \\
\hline 60.52 & 5.3 & Rice \\
\hline 60.54 & 6.6 & Burckle \\
\hline 60.79 & 5.3 & Rice \\
\hline 61.04 & 6.7 & Burckle \\
\hline 61.09 & 6.8 & Rice \\
\hline 61.51 & 14.3 & Rice \\
\hline 61.81 & 14.0 & Rice \\
\hline 62.04 & 13.3 & Rice \\
\hline 62.04 & 11.8 & Burckle \\
\hline 62.31 & 15.5 & Rice \\
\hline 62.54 & 14.1 & Rice \\
\hline 62.79 & 7.4 & Rice \\
\hline 63.02 & 6.1 & Rice \\
\hline 63.31 & 4.0 & Rice \\
\hline 63.53 & 4.9 & Rice \\
\hline 63.54 & 4.1 & Burckle \\
\hline 63.79 & 4.5 & Rice \\
\hline 64.04 & 4.8 & Rice \\
\hline 64.04 & 5.4 & Burckle \\
\hline 64.26 & 6.8 & Rice \\
\hline 64.51 & 7.2 & Rice \\
\hline 64.77 & 7.2 & Rice \\
\hline 65.02 & 6.7 & Rice \\
\hline 65.27 & 7.5 & Rice \\
\hline 65.52 & 10.1 & Rice \\
\hline 65.54 & 5.7 & Burckle \\
\hline 65.77 & 6.0 & Rice \\
\hline 66.02 & 5.0 & Rice \\
\hline 66.25 & 4.7 & Rice \\
\hline 66.52 & 5.2 & Rice \\
\hline 66.54 & 8.0 & Burckle \\
\hline 66.77 & 5.1 & Rice \\
\hline 67.04 & 5.9 & Rice \\
\hline 67.04 & 5.9 & Burckle \\
\hline 67.27 & 4.8 & Rice \\
\hline 67.52 & 7.3 & Rice \\
\hline 67.79 & 7.6 & Rice \\
\hline 68.02 & 7.0 & Rice \\
\hline
\end{tabular}


Appendix (continued).

\begin{tabular}{|c|c|c|}
\hline $\begin{array}{l}\text { Depth } \\
\text { (mbsf) }\end{array}$ & $\begin{array}{l}\text { Opal } \\
\text { (wt\%) }\end{array}$ & Source $^{a}$ \\
\hline 68.04 & 7.4 & Burckle \\
\hline 68.27 & 7.3 & Rice \\
\hline 68.52 & 10.7 & Rice \\
\hline 68.54 & 11.3 & Burckle \\
\hline 68.77 & 9.3 & Rice \\
\hline 68.99 & 5.1 & Rice \\
\hline 69.02 & 8.2 & Rice \\
\hline 69.30 & 8.9 & Rice \\
\hline 69.30 & 4.1 & Rice \\
\hline 69.30 & 4.2 & Burckle \\
\hline 69.52 & 6.9 & Rice \\
\hline 69.55 & 4.5 & Rice \\
\hline 69.77 & 8.6 & Rice \\
\hline 69.78 & 4.9 & Rice \\
\hline 69.80 & 5.2 & Burckle \\
\hline 70.05 & 5.3 & Rice \\
\hline 70.28 & 5.0 & Rice \\
\hline 70.49 & 6.1 & Rice \\
\hline 70.80 & 9.0 & Rice \\
\hline 70.80 & 8.8 & Burckle \\
\hline 71.05 & 9.9 & Rice \\
\hline 71.28 & 12.4 & Rice \\
\hline 71.30 & 13.4 & Burckle \\
\hline 71.55 & 11.8 & Rice \\
\hline 71.78 & 11.1 & Rice \\
\hline 71.99 & 10.7 & Rice \\
\hline 72.30 & 13.3 & Rice \\
\hline 72.30 & 12.8 & Burckle \\
\hline 72.55 & 11.2 & Rice \\
\hline 72.78 & 9.3 & Rice \\
\hline 72.80 & 9.0 & Burckle \\
\hline 73.05 & 13.1 & Rice \\
\hline 73.28 & 15.9 & Rice \\
\hline 73.49 & 12.0 & Rice \\
\hline 73.80 & 9.2 & Rice \\
\hline 73.80 & 8.2 & Burckle \\
\hline 74.05 & 7.7 & Rice \\
\hline 74.28 & 8.9 & Rice \\
\hline 74.30 & 9.7 & Burckle \\
\hline 74.55 & 11.8 & Rice \\
\hline 74.78 & 7.4 & Rice \\
\hline 74.90 & 7.8 & Burckle \\
\hline 74.99 & 8.3 & Rice \\
\hline 75.30 & 8.4 & Rice \\
\hline 75.30 & 9.2 & Burckle \\
\hline 75.55 & 9.4 & Rice \\
\hline 75.78 & 9.6 & Rice \\
\hline 75.80 & 10.0 & Burckle \\
\hline 76.05 & 9.6 & Rice \\
\hline 76.28 & 7.4 & Rice \\
\hline 76.49 & 7.3 & Rice \\
\hline 76.80 & 8.5 & Rice \\
\hline 76.80 & 9.3 & Burckle \\
\hline 77.05 & 7.7 & Rice \\
\hline 77.28 & 8.1 & Rice \\
\hline 77.30 & 8.6 & Burckle \\
\hline 77.55 & 10.0 & Rice \\
\hline 77.78 & 13.5 & Rice \\
\hline 77.90 & 5.1 & Burckle \\
\hline 77.99 & 12.5 & Rice \\
\hline 78.30 & 9.1 & Rice \\
\hline 78.50 & 5.1 & Burckle \\
\hline 78.55 & 11.1 & Rice \\
\hline 78.72 & 6.4 & Rice \\
\hline 79.00 & 4.3 & Burckle \\
\hline 79.02 & 4.4 & Rice \\
\hline 79.34 & 5.6 & Rice \\
\hline 79.90 & 6.7 & Burckle \\
\hline 80.12 & 5.7 & Rice \\
\hline 80.40 & 6.1 & Burckle \\
\hline 81.26 & 7.7 & Burckle \\
\hline 81.43 & 7.7 & Rice \\
\hline 81.76 & 10.9 & Burckle \\
\hline 82.76 & 12.2 & Burckle \\
\hline 83.26 & 9.9 & Burckle \\
\hline
\end{tabular}

Appendix (continued).

\begin{tabular}{|c|c|c|}
\hline $\begin{array}{l}\text { Depth } \\
\text { (mbsf) }\end{array}$ & $\begin{array}{c}\text { Opal } \\
\text { (wt\%) }\end{array}$ & Source ${ }^{a}$ \\
\hline 83.40 & 9.0 & Rice \\
\hline 84.26 & 12.0 & Burckle \\
\hline 84.76 & 11.4 & Burckle \\
\hline 85.76 & 11.2 & Burckle \\
\hline 86.10 & 15.0 & Rice \\
\hline 86.26 & 8.4 & Burckle \\
\hline 87.13 & 14.4 & Burckle \\
\hline 87.60 & 9.9 & Rice \\
\hline 87.70 & 11.5 & Burckle \\
\hline 87.84 & 11.9 & Rice \\
\hline 88.10 & 9.3 & Burckle \\
\hline 88.37 & 7.7 & Rice \\
\hline 88.72 & 14.6 & Burckle \\
\hline 89.22 & 11.9 & Burckle \\
\hline 90.01 & 16.7 & Rice \\
\hline 90.22 & 15.0 & Burckle \\
\hline 90.72 & 10.4 & Burckle \\
\hline 91.40 & 21.5 & Rice \\
\hline 91.72 & 10.7 & Burckle \\
\hline 92.22 & 12.9 & Burckle \\
\hline 92.90 & 12.3 & Rice \\
\hline 93.22 & 11.8 & Burckle \\
\hline 93.72 & 17.4 & Burckle \\
\hline 94.40 & 17.5 & Rice \\
\hline 94.72 & 10.8 & Burckle \\
\hline 95.22 & 10.4 & Burckle \\
\hline 95.90 & 11.5 & Rice \\
\hline 96.72 & & Burckle \\
\hline 97.40 & 6.2 & Rice \\
\hline 97.72 & 6.9 & Burckle \\
\hline 98.21 & 14.6 & Burckle \\
\hline 98.30 & 23.9 & Burckle \\
\hline 99.00 & 18.8 & Rice \\
\hline 99.30 & 16.5 & Burckle \\
\hline 99.80 & 12.9 & Burckle \\
\hline 100.50 & 10.6 & Rice \\
\hline 100.80 & 7.1 & Burckle \\
\hline 102.00 & 9.1 & Rice \\
\hline 102.30 & 11.9 & Burckle \\
\hline 102.80 & 16.8 & Burckle \\
\hline 103.50 & 15.5 & Rice \\
\hline 103.80 & 12.9 & Burckle \\
\hline 104.30 & 13.9 & Burckle \\
\hline 105.00 & 11.7 & Rice \\
\hline 105.30 & 5.6 & Burckle \\
\hline 105.80 & 6.0 & Burckle \\
\hline 106.50 & 7.8 & Rice \\
\hline 107.20 & 11.9 & Rice \\
\hline 107.50 & 12.5 & Burckle \\
\hline 107.96 & 12.4 & Rice \\
\hline 108.77 & 8.1 & Burckle \\
\hline 108.90 & 10.8 & Burckle \\
\hline 109.53 & 21.6 & Rice \\
\hline 109.77 & 20.1 & Burckle \\
\hline 110.27 & 19.8 & Burckle \\
\hline 111.03 & 18.6 & Rice \\
\hline 111.27 & 15.0 & Burckle \\
\hline 111.77 & 15.4 & Burckle \\
\hline 112.47 & 17.6 & Rice \\
\hline 112.77 & 11.9 & Burckle \\
\hline 112.85 & 7.1 & Pete798B \\
\hline 113.11 & 6.8 & Pete798B \\
\hline 113.36 & 8.1 & Pete798B \\
\hline 113.61 & 5.6 & Pete798B \\
\hline 113.86 & 7.3 & Pete798B \\
\hline 114.13 & 9.9 & Pete798B \\
\hline 114.37 & 8.2 & Pete798B \\
\hline 114.70 & 10.0 & Pete798B \\
\hline 114.92 & 12.5 & Pete798B \\
\hline 115.13 & 14.9 & Pete798B \\
\hline 115.38 & 15.0 & Pete798B \\
\hline 115.64 & 15.3 & Pete798B \\
\hline 115.89 & 15.0 & Pete798B \\
\hline 116.14 & 14.3 & Pete 798B \\
\hline 116.40 & 13.2 & Pete 798B \\
\hline
\end{tabular}


Appendix (continued).

\begin{tabular}{|c|c|c|}
\hline $\begin{array}{l}\text { Depth } \\
\text { (mbsf) }\end{array}$ & $\begin{array}{c}\text { Opal } \\
\text { (wt\%) }\end{array}$ & Source ${ }^{a}$ \\
\hline 116.65 & 9.8 & Pete798B \\
\hline 116.90 & 12.2 & Pete798B \\
\hline 117.16 & 12.8 & Pete798B \\
\hline 117.41 & 14.3 & Pete798B \\
\hline 117.67 & 12.9 & Pete 798B \\
\hline 117.92 & 11.9 & Pete 798B \\
\hline 118.17 & 8.7 & Pete798B \\
\hline 118.43 & 9.7 & Pete 798B \\
\hline 118.68 & 6.6 & Pete798B \\
\hline 118.93 & 3.9 & Pete798B \\
\hline 119.19 & 4.5 & Pete798B \\
\hline 119.44 & 8.9 & Pete798B \\
\hline 119.70 & 7.5 & Pete 798B \\
\hline 119.95 & 8.4 & Pete 798B \\
\hline 120.20 & 5.5 & Pete798B \\
\hline 120.46 & 6.1 & Pete 798B \\
\hline 120.71 & 8.7 & Pete798B \\
\hline 120.97 & 10.1 & Pete798B \\
\hline 121.22 & 13.2 & Pete798B \\
\hline 121.47 & 8.7 & Pete798B \\
\hline 121.73 & 13.4 & Pete798B \\
\hline 121.98 & 18.5 & Pete798B \\
\hline 122.25 & 17.1 & Pete798B \\
\hline 122.55 & 12.5 & Pete798B \\
\hline 122.80 & 9.4 & Pete798B \\
\hline 123.05 & 8.4 & Pete798B \\
\hline 123.31 & 7.6 & Pete798B \\
\hline 123.56 & 7.8 & Pete798B \\
\hline 123.89 & 10.9 & Pete798B \\
\hline 124.31 & 7.2 & Pete798B \\
\hline 124.56 & 6.9 & Pete798B \\
\hline 124.82 & 6.9 & Pete798B \\
\hline 125.07 & 8.2 & Pete798B \\
\hline 125.45 & 5.9 & Pete798B \\
\hline 125.79 & 7.3 & Pete 798B \\
\hline 126.08 & 6.7 & Pete798B \\
\hline 126.33 & 7.3 & Pete798B \\
\hline 126.58 & 11.3 & Pete798B \\
\hline 126.83 & 14.4 & Pete798B \\
\hline 127.08 & 9.5 & Pete798B \\
\hline 127.33 & 10.6 & Pete798B \\
\hline 127.59 & 16.8 & Pete798B \\
\hline 127.84 & 17.0 & Pete798B \\
\hline 128.09 & 13.1 & Pete798B \\
\hline 128.34 & 14.8 & Pete798B \\
\hline 128.59 & 14.4 & Pete798B \\
\hline 128.85 & 11.3 & Pete798B \\
\hline 129.10 & 9.9 & Pete798B \\
\hline 129.35 & 9.1 & Pete798B \\
\hline 129.60 & 8.2 & Pete798B \\
\hline 129.85 & 7.6 & Pete798B \\
\hline 130.10 & 5.5 & Pete798B \\
\hline 130.36 & 5.6 & Pete 798B \\
\hline 130.94 & 5.3 & Pete798B \\
\hline 131.20 & 4.7 & Pete798B \\
\hline 131.45 & 4.4 & Pete798B \\
\hline 131.70 & 4.7 & Pete798B \\
\hline 131.95 & 6.5 & Pete798B \\
\hline 132.25 & 12.1 & Pete798B \\
\hline 132.50 & 10.8 & Pete798B \\
\hline 132.76 & 11.5 & Pete798B \\
\hline 133.01 & 11.5 & Pete798B \\
\hline 133.23 & 8.3 & Pete798B \\
\hline 133.49 & 8.8 & Pete798B \\
\hline 133.91 & 8.8 & Pete798B \\
\hline 134.25 & 14.6 & Pete798B \\
\hline 134.51 & 8.4 & Pete798B \\
\hline 134.76 & 6.3 & Pete798B \\
\hline 135.01 & 5.4 & Pete798B \\
\hline 135.27 & 4.4 & Pete798B \\
\hline 135.52 & 7.6 & Pete 798B \\
\hline 135.78 & 7.3 & Pete798B \\
\hline 136.03 & 6.5 & Pete798B \\
\hline 136.28 & 8.2 & Pete798B \\
\hline 136.54 & 12.2 & Pete798B \\
\hline
\end{tabular}

Appendix (continued).

\begin{tabular}{|c|c|c|}
\hline $\begin{array}{l}\text { Depth } \\
\text { (mbsf) }\end{array}$ & $\begin{array}{c}\text { Opal } \\
\text { (wt\%) }\end{array}$ & Source ${ }^{a}$ \\
\hline 136.79 & 17.6 & Pete798B \\
\hline 137.05 & 19.1 & Pete798B \\
\hline 137.30 & 20.4 & Pete798B \\
\hline 137.56 & 20.7 & Pete798B \\
\hline 137.81 & 18.5 & Pete798B \\
\hline 138.32 & 15.1 & Pete798B \\
\hline 138.57 & 13.3 & Pete798B \\
\hline 138.83 & 10.4 & Pete798B \\
\hline 139.08 & 8.4 & Pete798B \\
\hline 139.34 & 12.2 & Pete798B \\
\hline 139.59 & 17.2 & Pete798B \\
\hline 139.84 & 15.2 & Pete798B \\
\hline 140.04 & 10.3 & Pete798B \\
\hline 140.35 & 6.6 & Pete798B \\
\hline 140.61 & 6.2 & Pete798B \\
\hline 140.86 & 6.2 & Pete798B \\
\hline 141.12 & 6.9 & Pete798B \\
\hline 141.37 & 11.8 & Pete798B \\
\hline 141.65 & 10.9 & Pete798B \\
\hline 142.30 & 15.0 & Burckle2 \\
\hline 142.80 & 19.0 & Burckle2 \\
\hline 143.49 & 23.2 & Burckle2 \\
\hline 144.03 & 14.2 & Rice \\
\hline 144.48 & 21.9 & Burckle2 \\
\hline 144.98 & 22.0 & Burckle2 \\
\hline 145.44 & 20.6 & Rice \\
\hline 145.98 & 20.9 & Burckle2 \\
\hline 146.48 & 22.2 & Burckle2 \\
\hline 146.94 & 26.0 & Rice \\
\hline 147.48 & 25.3 & Burckle2 \\
\hline 147.98 & 25.1 & Burckle2 \\
\hline 148.98 & 26.2 & Burckle2 \\
\hline 149.48 & 26.6 & Burckle2 \\
\hline 150.48 & 25.4 & Burckle2 \\
\hline 150.98 & 24.8 & Burckle2 \\
\hline 151.28 & 27.8 & Burckle2 \\
\hline 152.78 & 27.0 & Burckle2 \\
\hline 153.28 & 26.2 & Burckle2 \\
\hline 154.28 & 29.9 & Burckle2 \\
\hline 154.78 & 27.5 & Burckle2 \\
\hline 155.78 & 23.7 & Burckle2 \\
\hline 156.28 & 23.8 & Burckle2 \\
\hline 157.28 & 22.9 & Burckle2 \\
\hline 158.40 & 21.5 & Burckle2 \\
\hline 158.78 & 22.8 & Burckle2 \\
\hline 159.28 & 22.4 & Burckle2 \\
\hline 160.28 & 5.6 & Burckle2 \\
\hline 160.78 & 7.0 & Burckle2 \\
\hline 161.60 & 11.7 & Burckle2 \\
\hline 162.10 & 14.5 & Burckle2 \\
\hline 163.10 & 23.7 & Burckle2 \\
\hline 163.60 & 13.3 & Burckle2 \\
\hline 164.60 & 18.7 & Burckle2 \\
\hline 165.10 & 23.6 & Burckle2 \\
\hline 166.10 & 29.4 & Burckle2 \\
\hline 166.60 & 29.7 & Burckle2 \\
\hline 167.60 & 14.9 & Burckle2 \\
\hline 168.10 & 14.8 & Burckle2 \\
\hline 170.90 & 15.3 & Burckle2 \\
\hline 170.95 & 13.7 & Pete798B \\
\hline 171.25 & 10.8 & Pete798B \\
\hline 171.30 & 12.0 & Burckle2 \\
\hline 171.54 & 14.7 & Pete798B \\
\hline 171.80 & 19.9 & Burckle2 \\
\hline 171.85 & 22.5 & Pete798B \\
\hline 172.15 & 21.3 & Pete798B \\
\hline 172.45 & 21.8 & Pete 798B \\
\hline 172.77 & 18.4 & Pete798B \\
\hline 172.80 & 17.9 & Burckle2 \\
\hline 173.10 & 15.5 & Pete798B \\
\hline 173.30 & 13.6 & Burckle2 \\
\hline 173.40 & 11.2 & Pete798B \\
\hline 173.70 & 14.1 & Pete798B \\
\hline 174.00 & 9.9 & Pete798B \\
\hline 174.29 & 9.1 & Pete798B \\
\hline
\end{tabular}


Appendix (continued).

\begin{tabular}{|c|c|c|}
\hline $\begin{array}{l}\text { Depth } \\
\text { (mbsf) }\end{array}$ & $\begin{array}{c}\text { Opal } \\
\text { (wt\%) }\end{array}$ & Source ${ }^{a}$ \\
\hline 174.30 & 9.5 & Burckle2 \\
\hline 174.60 & 12.6 & Pete798B \\
\hline 174.80 & 11.7 & Burckle2 \\
\hline 174.90 & 10.3 & Pete798B \\
\hline 175.20 & 8.0 & Pete798B \\
\hline 175.50 & 8.9 & Pete798B \\
\hline 175.79 & 7.6 & Pete798B \\
\hline 175.80 & 7.7 & Burckle2 \\
\hline 176.10 & 11.0 & Pete798B \\
\hline 176.30 & 18.8 & Burckle2 \\
\hline 176.40 & 20.0 & Pete798B \\
\hline 176.70 & 21.6 & Pete 798B \\
\hline 177.00 & 24.0 & Pete798B \\
\hline 177.28 & 20.6 & Pete798B \\
\hline 177.30 & 23.6 & Burckle2 \\
\hline 177.61 & 17.6 & Pete798B \\
\hline 177.80 & 21.5 & Burckle2 \\
\hline 177.90 & 16.2 & Pete798B \\
\hline 178.23 & 10.9 & Pete798B \\
\hline 178.55 & 8.8 & Pete798B \\
\hline 178.80 & 6.7 & Burckle2 \\
\hline 178.86 & 6.5 & Pete798B \\
\hline 179.21 & 6.1 & Pete798B \\
\hline 179.30 & 5.4 & Burckle2 \\
\hline 179.56 & 6.0 & Pete798B \\
\hline 179.85 & 6.2 & Pete798B \\
\hline 180.59 & 8.5 & Burckle2 \\
\hline 180.64 & 8.2 & Pete798B \\
\hline 180.90 & 7.2 & Pete798B \\
\hline 181.16 & 6.6 & Pete798B \\
\hline 181.43 & 6.8 & Pete798B \\
\hline 181.67 & 9.1 & Pete798B \\
\hline 181.96 & 12.8 & Pete798B \\
\hline 181.97 & 7.4 & Burckle2 \\
\hline 182.29 & 10.5 & Pete798B \\
\hline 182.47 & 6.7 & Burckle2 \\
\hline 182.57 & 7.0 & Pete798B \\
\hline 182.84 & 10.6 & Pete798B \\
\hline 183.07 & 15.8 & Pete798B \\
\hline 183.47 & 12.5 & Burckle2 \\
\hline 183.47 & 10.2 & Burckle2 \\
\hline 183.97 & 15.7 & Burckle2 \\
\hline 184.06 & 19.1 & Pete798B \\
\hline 184.37 & 10.6 & Pete798B \\
\hline 184.69 & 19.3 & Pete798B \\
\hline 184.96 & 22.1 & Pete798B \\
\hline 185.02 & 17.0 & Pete798B \\
\hline 185.26 & 22.8 & Pete798B \\
\hline 185.73 & 26.8 & Pete798B \\
\hline 185.97 & 23.7 & Pete798B \\
\hline 186.23 & 19.2 & Pete798B \\
\hline 186.47 & 23.2 & Burckle2 \\
\hline 186.75 & 22.5 & Pete798B \\
\hline 186.97 & 24.8 & Burckle2 \\
\hline 187.31 & 20.2 & Pete798B \\
\hline 187.78 & 12.9 & Pete798B \\
\hline 187.97 & 20.3 & Burckle2 \\
\hline 188.14 & 19.2 & Pete798B \\
\hline 188.47 & 16.4 & Pete798B \\
\hline 188.47 & 23.8 & Burckle2 \\
\hline 188.71 & 17.8 & Pete798B \\
\hline 188.97 & 13.8 & Pete798B \\
\hline 189.20 & 17.0 & Pete798B \\
\hline 189.44 & 8.9 & Pete798B \\
\hline 189.97 & 20.6 & Burckle2 \\
\hline 190.29 & 13.7 & Burckle2 \\
\hline 190.70 & 14.7 & Burckle2 \\
\hline 191.51 & 16.0 & Burckle2 \\
\hline 192.01 & 17.6 & Burckle2 \\
\hline 193.51 & 27.1 & Burckle2 \\
\hline 194.51 & 17.5 & Burckle2 \\
\hline 195.01 & 17.8 & Burckle2 \\
\hline 196.01 & 13.6 & Burckle2 \\
\hline 196.21 & 8.9 & RiceB \\
\hline 196.51 & 7.0 & Burckle2 \\
\hline
\end{tabular}

Appendix (continued).

\begin{tabular}{|c|c|c|}
\hline $\begin{array}{l}\text { Depth } \\
\text { (mbsf) }\end{array}$ & $\begin{array}{c}\text { Opal } \\
\text { (wt\%) }\end{array}$ & Source $^{a}$ \\
\hline 197.51 & 6.2 & Burckle2 \\
\hline 197.71 & 7 & RiceB \\
\hline 198.01 & 11.7 & Burckle2 \\
\hline 199.01 & 24.0 & Burckle2 \\
\hline 199.21 & 29.3 & RiceB \\
\hline 200.59 & 25.3 & RiceB \\
\hline 200.96 & 23.3 & Burckle2 \\
\hline 202.08 & 32.3 & RiceB \\
\hline 203.58 & 29.9 & RiceB \\
\hline 208.04 & 12.4 & RiceB \\
\hline 209.08 & 11.8 & RiceB \\
\hline 210.02 & 26.8 & RiceB \\
\hline 210.65 & 8.6 & RiceB \\
\hline 211.75 & 27.4 & RiceB \\
\hline 213.08 & 36.5 & RiceB \\
\hline 213.87 & 33.3 & RiceB \\
\hline 216.34 & 28.7 & RiceB \\
\hline 217.54 & 11.3 & RiceB \\
\hline 219.3 & 16.5 & RiceB \\
\hline 219.83 & 30.9 & RiceB \\
\hline 220.09 & 16.4 & RiceB \\
\hline 220.75 & 11.2 & RiceB \\
\hline 221.1 & 24.5 & RiceB \\
\hline 222.36 & 21.1 & RiceB \\
\hline 223.93 & 29.8 & RiceB \\
\hline 225.57 & 29.6 & RiceB \\
\hline 226.80 & 23.5 & Burckle2 \\
\hline 227.55 & 18.4 & RiceB \\
\hline 228.35 & 20.8 & RiceB \\
\hline 229.00 & 12.2 & Burckle2 \\
\hline 229.07 & 18.5 & RiceB \\
\hline 230.19 & 30.8 & RiceB \\
\hline 230.95 & 31.6 & RiceB \\
\hline 233.17 & 24.2 & RiceB \\
\hline 234.31 & 30.2 & RiceB \\
\hline 235.81 & 30.2 & RiceB \\
\hline 248.30 & 7.5 & Burckle2 \\
\hline 248.95 & 9.3 & RiceB \\
\hline 250.44 & 17.1 & RiceB \\
\hline 251.95 & 22.9 & RiceB \\
\hline 253.46 & 24.2 & RiceB \\
\hline 255 & 17.9 & RiceB \\
\hline 256.5 & 10.6 & RiceB \\
\hline 257.64 & 42.1 & RiceB \\
\hline 258.03 & 24.2 & Pete798B \\
\hline 258.30 & 22.8 & Pete798B \\
\hline 258.35 & 21.9 & RiceB \\
\hline 258.60 & 24.0 & Pete798B \\
\hline 258.90 & 22.6 & Pete798B \\
\hline 259.19 & 24.4 & Pete798B \\
\hline 259.48 & 17.1 & Pete798B \\
\hline 259.78 & 15.1 & Pete798B \\
\hline 259.92 & 19 & RiceB \\
\hline 260.14 & 13.7 & Pete798B \\
\hline 260.49 & 15.3 & Pete798B \\
\hline 260.79 & 13.3 & Pete798B \\
\hline 261.10 & 16.1 & Pete798B \\
\hline 261.45 & 18.2 & Pete798B \\
\hline 261.79 & 18.4 & Pete798B \\
\hline 262.18 & 19.6 & Pete798B \\
\hline 262.52 & 20.2 & Pete798B \\
\hline 262.80 & 21.9 & Pete798B \\
\hline 263.13 & 24.1 & Pete 798B \\
\hline 263.40 & 25.6 & Pete798B \\
\hline 263.81 & 29.2 & Pete798B \\
\hline 264.09 & 28.8 & Pete798B \\
\hline 264.40 & 30.3 & Pete798B \\
\hline 264.71 & 28.2 & Pete798B \\
\hline 265.02 & 27.7 & Pete798B \\
\hline 265.33 & 30.1 & Pete 798B \\
\hline 265.49 & 35.6 & Burckle2 \\
\hline 265.62 & 29.6 & Pete798B \\
\hline 265.91 & 29.8 & Pete 798B \\
\hline 266.30 & 30.4 & Pete798B \\
\hline 266.69 & 29.5 & Pete798B \\
\hline
\end{tabular}


Appendix (continued).

\begin{tabular}{|c|c|c|}
\hline $\begin{array}{l}\text { Depth } \\
\text { (mbsf) }\end{array}$ & $\begin{array}{c}\text { Opal } \\
(\text { wt } \%)\end{array}$ & Source $^{a}$ \\
\hline 266.98 & 29.8 & Pete798B \\
\hline 267.27 & 30.0 & Pete798B \\
\hline 267.59 & 11.2 & Burckle2 \\
\hline 267.64 & 11.5 & Pete798B \\
\hline 267.89 & 11.0 & Pete798B \\
\hline 268.14 & 13.3 & Pete798B \\
\hline 268.41 & 15.6 & Pete798B \\
\hline 268.67 & 30.3 & Pete798B \\
\hline 268.95 & 31.3 & Pete798B \\
\hline 268.95 & 32.0 & Pete798B \\
\hline 269.22 & 40.4 & Pete798B \\
\hline 269.22 & 34.6 & Pete798B \\
\hline 269.47 & 42.8 & Pete798B \\
\hline 269.47 & 36.2 & Pete798B \\
\hline 269.70 & 31.8 & Pete798B \\
\hline 269.95 & 28.5 & Pete798B \\
\hline 270.21 & 29.3 & Pete798B \\
\hline 270.21 & 29.4 & Pete798B \\
\hline 270.50 & 30.7 & Pete798B \\
\hline 270.76 & 30.1 & Pete798B \\
\hline 271.03 & 27.1 & Pete798B \\
\hline 271.03 & 26.8 & Pete798B \\
\hline 271.37 & 26.9 & Pete798B \\
\hline 271.73 & 28.1 & Pete798B \\
\hline 271.98 & 26.9 & Pete798B \\
\hline 272.23 & 26.6 & Pete798B \\
\hline 272.23 & 21.2 & Pete798B \\
\hline 272.49 & 23.7 & Pete798B \\
\hline 272.76 & 21.2 & Pete798B \\
\hline 273.00 & 19.8 & Pete798B \\
\hline 273.27 & 15.4 & Pete798B \\
\hline 273.27 & 15.2 & Pete798B \\
\hline 273.55 & 16.0 & Pete798B \\
\hline 273.80 & 20.4 & Pete798B \\
\hline 273.85 & 19.2 & Pete798B \\
\hline 273.85 & 18.7 & Pete 798B \\
\hline 274.53 & 21.9 & Pete798B \\
\hline 274.79 & 25.1 & Pete798B \\
\hline 275.04 & 27.0 & Pete798B \\
\hline 275.04 & 26.0 & Pete798B \\
\hline 275.30 & 27.8 & Pete798B \\
\hline 275.30 & 26.8 & Pete798B \\
\hline 275.55 & 25.5 & Pete798B \\
\hline 275.55 & 21.2 & Pete798B \\
\hline 275.81 & 25.5 & Pete798B \\
\hline 276.06 & 23.6 & Pete798B \\
\hline 276.31 & 26.1 & Pete798B \\
\hline 276.55 & 21.3 & Pete798B \\
\hline 276.93 & 21.5 & Pete798B \\
\hline 277.31 & 20.4 & Pete798B \\
\hline 277.65 & 18.8 & Pete798B \\
\hline 278.10 & 13.0 & Pete798B \\
\hline 278.51 & 8.0 & Pete 798B \\
\hline 278.79 & 7.1 & Pete798B \\
\hline 279.39 & 7.3 & Pete798B \\
\hline 279.69 & 6.4 & Pete798B \\
\hline 279.99 & 7.7 & Pete798B \\
\hline 280.32 & 7.0 & Pete798B \\
\hline 280.70 & 6.9 & Pete798B \\
\hline 281.04 & 7.2 & Pete798B \\
\hline 281.53 & 13.8 & Pete798B \\
\hline 281.82 & 12.2 & Pete798B \\
\hline 282.13 & 15.4 & Pete798B \\
\hline 282.42 & 9.0 & Pete798B \\
\hline 282.74 & 5.4 & Pete798B \\
\hline 283.05 & 3.6 & Pete798B \\
\hline 283.45 & 4.6 & Pete798B \\
\hline 283.60 & 8.0 & Burckle2 \\
\hline 283.76 & 7.3 & Pete798B \\
\hline 284.05 & 12.0 & Pete798B \\
\hline 284.37 & 16.3 & Pete798B \\
\hline 284.67 & 15.1 & Pete798B \\
\hline 285.02 & 11.0 & Pete798B \\
\hline 285.71 & 28.1 & Pete798B \\
\hline 285.71 & 28.0 & Burckle2 \\
\hline
\end{tabular}

Appendix (continued).

\begin{tabular}{|c|c|c|}
\hline $\begin{array}{l}\text { Depth } \\
\text { (mbsf) }\end{array}$ & $\begin{array}{c}\text { Opal } \\
\text { (wt\%) }\end{array}$ & Source ${ }^{a}$ \\
\hline 286.00 & 26.4 & Pete798B \\
\hline 286.28 & 26.8 & Pete798B \\
\hline 286.56 & 25.9 & Pete798B \\
\hline 286.84 & 24.9 & Pete798B \\
\hline 287.12 & 24.8 & Pete798B \\
\hline 287.39 & 25.8 & Pete798B \\
\hline 287.67 & 24.9 & Pete798B \\
\hline 288.58 & 26.2 & Pete798B \\
\hline 288.87 & 24.2 & Pete798B \\
\hline 289.18 & 24.2 & Pete798B \\
\hline 289.48 & 22.7 & Pete798B \\
\hline 289.81 & 17.7 & Pete798B \\
\hline 290.20 & 24.0 & Pete798B \\
\hline 290.49 & 28.4 & Pete798B \\
\hline 290.79 & 29.7 & Pete798B \\
\hline 291.45 & 23.4 & Pete798B \\
\hline 291.77 & 25.0 & Pete798B \\
\hline 292.07 & 23.0 & Pete798B \\
\hline 292.40 & 21.4 & Pete798B \\
\hline 292.40 & 21.4 & Pete798B \\
\hline 292.68 & 22.5 & \\
\hline 292.95 & 23.5 & Pete798B \\
\hline 293.39 & 20.6 & Pete798B \\
\hline 293.81 & 21.7 & Pete798B \\
\hline 294.09 & 20.8 & Pete798B \\
\hline 294.36 & 21.6 & Pete798B \\
\hline 294.63 & 22.5 & Pete798B \\
\hline 294.92 & 27.9 & Pete \\
\hline 295.14 & 22.7 & Pete 79 \\
\hline 295.35 & 27.3 & Pete798B \\
\hline 295.67 & 28.7 & Pete798B \\
\hline 295.95 & 26.6 & Pete798B \\
\hline 296.25 & 27.5 & Pete798B \\
\hline 296.56 & 26.1 & Pete798B \\
\hline 296.80 & 25.7 & Burckle2 \\
\hline 296.86 & 25.8 & Pete798B \\
\hline 297.15 & 23.6 & $8 \mathrm{~B}$ \\
\hline 297.43 & 21.8 & Pete798B \\
\hline 297.74 & 24.8 & Pete798B \\
\hline 298.07 & 26.0 & Pete798B \\
\hline 298.44 & 23.4 & Pete798B \\
\hline 298.84 & 29.1 & Pete798B \\
\hline 299.13 & 27.4 & Pete798B \\
\hline 299.57 & 28.9 & Pete798B \\
\hline 300.01 & 28.6 & Pete79 \\
\hline 300.62 & 30.7 & Pete798B \\
\hline 301.21 & 26.1 & Pete798B \\
\hline 301.51 & 16.9 & Pete798B \\
\hline 302.17 & 14.6 & Pete798B \\
\hline 302.69 & 15.4 & Pete798B \\
\hline 303.16 & 13.7 & Pete798B \\
\hline 303.64 & 11.5 & Pete798B \\
\hline 303.93 & 9.3 & Pete 79 \\
\hline 304.24 & 10.5 & Pete798B \\
\hline 304.54 & 16.4 & Pete798B \\
\hline 304.78 & 29.6 & Pete798B \\
\hline 304.99 & 26.9 & Burckle2 \\
\hline 305.06 & 25.3 & Pete798B \\
\hline 305.40 & 25.9 & Pete798B \\
\hline 305.73 & 25.8 & Pete798B \\
\hline 306.01 & 24.8 & Pete798B \\
\hline 306.32 & 23.1 & Pete798B \\
\hline 306.64 & 21.2 & Pete798B \\
\hline 306.93 & 23.6 & Pete798B \\
\hline 307.23 & 23.5 & Pete798B \\
\hline 307.73 & 22.2 & Pete798B \\
\hline 308.23 & 22.4 & Pete798B \\
\hline 308.49 & 21.3 & Pete798B \\
\hline 309.19 & 19.8 & Pete798B \\
\hline 309.54 & 20.6 & Pete798B \\
\hline 310.45 & 20.6 & Pete798B \\
\hline 310.73 & 22.6 & Pete798B \\
\hline 311.05 & 20.7 & Pete798B \\
\hline 311.35 & 24.3 & Pete798B \\
\hline 311.93 & 22.7 & Pete798B \\
\hline
\end{tabular}


Appendix (continued).

\begin{tabular}{|c|c|c|}
\hline $\begin{array}{l}\text { Depth } \\
\text { (mbsf) }\end{array}$ & $\begin{array}{c}\text { Opal } \\
\text { (wt\%) }\end{array}$ & Source ${ }^{a}$ \\
\hline 312.17 & 23.0 & Pete798B \\
\hline 312.81 & 21.6 & Pete798B \\
\hline 313.14 & 21.7 & Pete798B \\
\hline 313.43 & 20.3 & Pete 798B \\
\hline 313.90 & 19.3 & Pete798B \\
\hline 314.36 & 19.4 & Pete798B \\
\hline 314.60 & 24.0 & Burckle2 \\
\hline 324.29 & 9.1 & Burckle2 \\
\hline 333.81 & 6.3 & Burckle2 \\
\hline 343.61 & 7.1 & Burckle2 \\
\hline 360.74 & 13.5 & Burckle2 \\
\hline 362.88 & 17.7 & Burckle2 \\
\hline 373.98 & 12.4 & Burckle2 \\
\hline 382.15 & 9.3 & Burckle2 \\
\hline 398.20 & 3.7 & Burckle2 \\
\hline
\end{tabular}

Rice $=$ Hole 798A ( $+3.2-\mathrm{m}$ correction); RiceB $=$ Hole 798B $(-4 \mathrm{~m}$ relative to Hole $798 \mathrm{~A}$, i.e., $-0.8 \mathrm{~m}) ; \mathrm{RiceC}=\mathrm{Hole} 798 \mathrm{C}$ $(0-\mathrm{m}$ correction $) ;$ Burckle $=$ Hole 798 A $(+3.2-\mathrm{m}$ correction $)$;

Burckle2 $=$ Hole 798B $(-4$ m relative to Hole 798A, i.e., -0.8 $\mathrm{m})$ : Pete 798B $=$ Hole $798 \mathrm{~B}(-4 \mathrm{~m}$ relative to Hole $798 \mathrm{~A}$, i.e., $-0.8 \mathrm{~m}$ ). 